\title{
Synthesis and characterization of mRNA cap analogs containing phosphorothioate substitutions that bind tightly to elF4E and are resistant to the decapping pyrophosphatase DcpS
}

\author{
JOANNA KOWALSKA, ${ }^{1}$ MAGDALENA LEWDOROWICZ, ${ }^{1}$ JOANNA ZUBEREK, ${ }^{1}$ EWA GRUDZIEN-NOGALSKA, ${ }^{2}$ \\ ELZBIETA BOJARSKA, ${ }^{1}$ JANUSZ STEPINSKI, ${ }^{1}$ ROBERT E. RHOADS, ${ }^{2}$ EDWARD DARZYNKIEWICZ, ${ }^{1}$ \\ RICHARD E. DAVIS, ${ }^{3}$ and JACEK JEMIELITY ${ }^{1}$ \\ ${ }^{1}$ Division of Biophysics, University of Warsaw, 02-089 Warsaw, Poland \\ ${ }^{2}$ Department of Biochemistry and Molecular Biology, Louisiana State University Health Sciences Center, Shreveport, Louisiana 71130-3932, USA \\ ${ }^{3}$ Department of Biochemistry and Molecular Genetics, University of Colorado Health Sciences Center, 12801 East 17th Avenue, \\ Aurora, Colorado 80045, USA
}

\begin{abstract}
Analogs of the mRNA cap are widely employed to study processes involved in mRNA metabolism as well as being useful in biotechnology and medicinal applications. Here we describe synthesis of six dinucleotide cap analogs bearing a single phosphorothioate modification at either the $\alpha, \beta$, or $\gamma$ position of the $5^{\prime}, 5^{\prime}$-triphosphate chain. Three of them were also modified with methyl groups at the $2^{\prime}$ - $O$ position of 7 -methylguanosine to produce anti-reverse cap analogs (ARCAs). Due to the presence of stereogenic $\mathbf{P}$ centers in the phosphorothioate moieties, each analog was obtained as a mixture of two diastereomers, D1 and D2. The mixtures were resolved by RP HPLC, providing 12 different compounds. Fluorescence quenching experiments were employed to determine the association constant $\left(K_{\mathrm{AS}}\right)$ for complexes of the new analogs with elF4E. We found that phosphorothioate modifications generally stabilized the complex between eIF4E and the cap analog. The most strongly bound phosphorothioate analog (the D1 isomer of the $\beta$-substituted analog $\mathrm{m}^{7} \mathrm{Gpp} \mathrm{sG}$ ) was characterized by a $K_{\mathrm{AS}}$ that was more than fourfold higher than that of its unmodified counterpart $\left(m^{7} G p p G\right)$. All analogs modified in the $\gamma$ position were resistant to hydrolysis by the scavenger decapping pyrophosphatase DcpS from both human and Caenorhabditis elegans sources. The absolute configurations of the diastereomers D1 and D2 of analogs modified at the $\alpha$ position (i.e., $\mathrm{m}^{7} \mathrm{Gppp}_{\mathrm{S}} \mathrm{G}$ and $\left.\mathrm{m}_{2}{ }^{7,2^{\prime}-O} \mathrm{Gpp} \mathrm{p}_{\mathrm{S}} \mathrm{G}\right)$ were established as $S_{P}$ and $\boldsymbol{R}_{P}$, respectively, using enzymatic digestion and correlation with the $S_{P}$ and $R_{P}$ diastereomers of guanosine $5^{\prime}$-O-(1-thiodiphosphate) (GDP $\alpha$ S). The analogs resistant to DcpS act as potent inhibitors of in vitro protein synthesis in rabbit reticulocyte lysates.
\end{abstract}

Keywords: phosphorothioate cap analogs; ARCA; decapping enzymes; DcpS; binding affinity for elF4E; resistance to enzymatic hydrolysis

\section{INTRODUCTION}

A distinctive feature of all eukaryotic cellular mRNAs is the presence of a "cap" structure at their 5' ends. The typical cap consists of 7-methylguanosine connected via a $5^{\prime}, 5^{\prime}$ triphosphate bridge to the first nucleotide of the transcript. The cap plays a key role in a variety of cellular processes

Reprint requests to: Jacek Jemielity, Divison of Biophysics, University of Warsaw, Zwirki i Wigury 93, 02-089 Warsaw, Poland; e-mail: jacekj@ biogeo.uw.edu.pl; fax: 48-22-5540771.

Article published online ahead of print. Article and publication date are at http://www.rnajournal.org/cgi/doi/10.1261/rna.990208. related to mRNA metabolism including splicing, intracellular transport, translation, translational repression, and turnover (Furuichi and Shatkin 2000; Richter and Sonenberg 2005). Synthetic cap analogs have served as useful tools for elucidating these physiological processes. Most progress has occurred in studies on the initiation of protein synthesis, but, more recently, modified cap analogs have yielded new insights into the degradation of mRNA (Grudzien et al. 2006; Grudzien-Nogalska et al. 2007).

During the initiation of translation, the cap is specifically recognized by eukaryotic initiation factor $4 \mathrm{E}$ (eIF4E), which participates in the recruitment of ribosomes to 
mRNA by virtue of its binding to eIF4G. This process is the rate-limiting step for initiation of translation under normal circumstances (absence of virus infection, cellular stress, etc.) and plays a central role in the regulation of translation (Gingras et al. 1999). Structural requirements for the capeIF4E interaction were elucidated, in a large measure, by determining the binding affinities of variously modified mono- and dinucleotide cap analogs for eIF4E (McCubbin et al. 1988; Carberry et al. 1989; Niedzwiecka et al. 2002), and comparing their activity as inhibitors of cap-dependent translation in cell-free systems (Cai et al. 1999 and citations therein). The inhibitory potency of individual analogs generally correlates well with their binding affinities for eIF4E. One motivation for designing cap analog inhibitors of eIF4E with higher affinity is for potential applications in anti-cancer therapy, since eIF4E is overexpressed in many types of tumor cells and since elevated eIF4E levels selectively increase translation of mRNAs important in malignant transformation and metastasis (De Benedetti and Graff 2004).

Capped mRNAs have found broad application for in vitro protein synthesis as well as for obtaining expression of exogenous mRNAs in living cells. Synthetic dinucleotide cap analogs serve as useful tools to obtain $5^{\prime}$-capped mRNAs via transcription in vitro. This is achieved by transcribing DNA template with either a bacterial (Contreras et al. 1982) or bacteriophage (Konarska et al. 1984; Yisraeli and Melton 1989) RNA polymerase in the presence of all four NTPs and a cap dinucleotide such as $\mathrm{m}^{7} \mathrm{GpppG}$. These polymerases initiate transcription with nucleophilic attack by the $3^{\prime}-\mathrm{OH}$ of the guanosine (Guo) moiety in $\mathrm{m}^{7} \mathrm{GpppG}$ on the $\alpha$ phosphate of the next nucleoside triphosphate specified by the DNA template. Unfortunately, attack can also occur by the $3^{\prime}-\mathrm{OH}$ of the $\mathrm{m}^{7} \mathrm{Guo}$, producing onethird to one-half of the transcripts capped in a reverse orientation, i.e., Gpppm ${ }^{7} \mathrm{GpNpN}$... instead of $\mathrm{m}^{7} \mathrm{Gppp}$ GpNpN... (Pasquinelli et al. 1995). Such reverse-capped transcripts decrease the overall translational activity of the mRNA. This problem was overcome by the introduction of anti-reverse cap analogs (ARCAs) bearing either 3'-Omethyl, $3^{\prime}-\mathrm{H}$, or $2^{\prime}-\mathrm{O}$-methyl modification in the $\mathrm{m}^{7}$ Guo moiety, ensuring 100\% correct orientation (Stepinski et al. 2001; Peng et al. 2002; Jemielity et al. 2003). ARCAcapped mRNAs were shown to have higher translational efficiency in vitro (Stepinski et al. 2001; Jemielity et al. 2003) as well as in cultured cells (Grudzien et al. 2006). Moreover, it is possible to increase mRNA translational efficiency by introducing further modifications, e.g., extending the length of the $5^{\prime}, 5^{\prime}$-bridge (Jemielity et al. 2003).

Although a great number of cap analogs with various biochemical properties have been synthesized and exhaustively characterized, there have been few reports about analogs that are resistant to enzymatic hydrolysis. In eukaryotic cells there are two types of decapping enzymes, differing in their biological function, substrate specificity, and regioselectivity of hydrolysis (Coller and Parker 2004). One of them, DcpS, is involved in the $3^{\prime} \rightarrow 5^{\prime}$ mRNA degradation pathway. DcpS utilizes free $\mathrm{m}^{7} \mathrm{GpppN}$ dinucleotides as well as short capped mRNAs released after mRNA 3'-deadenylation and degradation by the exosome, but it is unable to cleave cap structures attached to long RNA chains (Liu et al. 2002). The enzyme cleaves the cap regioselectively between the $\beta$ and $\gamma$ phosphates of the $5^{\prime}, 5^{\prime}$-triphosphate bridge to release $\mathrm{m}^{7} \mathrm{GMP}$ and a downstream (oligo)nucleotide. A second decapping enzyme, the Dcp1/Dcp2 complex, is involved in the $5^{\prime} \rightarrow 3^{\prime}$ mRNA degradation pathway, in which deadenylation is followed by decapping and subsequent exonucleolitic digestion in the $5^{\prime} \rightarrow 3^{\prime}$ direction. Dcp2, the catalytic subunit of Dcp1/ Dcp2, cleaves the cap between the $\alpha$ and $\beta$ phosphates to release $\mathrm{m}^{7} \mathrm{GDP}$ and a $5^{\prime}$-phosphorylated mRNA chain (van Dijk et al. 2002; Wang et al. 2002), which is exposed to digestion by the exonuclease Xrn1.

In previous work, we designed and synthesized a series of cap analogs selectively modified with a methylenebisphosphonate moiety at either the $\alpha / \beta$ or $\beta / \gamma$ position of the $5^{\prime}, 5^{\prime}$ triphosphate bridge, i.e., $\mathrm{m}^{7} \mathrm{Gpp}_{\mathrm{CH} 2} \mathrm{pG}, \mathrm{m}_{2}{ }^{7,3^{\prime}-\mathrm{O}} \mathrm{Gpp}_{\mathrm{CH} 2} \mathrm{pG}$, $\mathrm{m}^{7} \mathrm{Gp}_{\mathrm{CH} 2} \mathrm{ppG}, \mathrm{m}_{2}{ }^{73^{\prime}-O} \mathrm{Gp}_{\mathrm{CH} 2} \mathrm{ppG}$, that were predicted to be resistant to either Dcp1/Dcp2 or DcpS (Kalek et al. 2006). Several of these analogs were resistant toward DcpS, which allowed us to determine their equilibrium association with hDcpS (Kalek et al. 2006). When analogs containing the ARCA modification were incorporated into mRNA, it was found that mRNA capped with $\mathrm{m}_{2}{ }^{7,3^{\prime}-\mathrm{O}} \mathrm{Gpp}_{\mathrm{CH} 2} \mathrm{pG}$, but not $\mathrm{m}_{2}{ }^{73^{\prime}-\mathrm{O}} \mathrm{Gp}_{\mathrm{CH} 2} \mathrm{ppG}$, was resistant to Dcp2 in vitro and stabilized mRNA in cultured cells (Grudzien et al. 2006). However, the translational efficiency of $\mathrm{m}_{2}{ }^{7,3^{\prime}-\mathrm{O}} \mathrm{Gpp}_{\mathrm{CH}} \mathrm{pG}$ capped mRNA was diminished compared with the parent $\mathrm{m}_{2}^{7,3^{\prime}-O}$ GpppG-capped mRNA. A possible explanation for the observed reduction in translation may be related to the lower binding affinity of eIF4E for $\mathrm{m}_{2}^{7,3^{\prime}-\mathrm{O}} \mathrm{Gpp}_{\mathrm{CH}} \mathrm{pG}$ compared with $\mathrm{m}_{2}^{7,3^{\prime}-O} \mathrm{GpppG}$ (Kalek et al. 2005).

In the present study, we sought to develop cap analogs that retained high affinity for eIF4E, yet were resistant to cleavage by pyrophosphatases. In particular, we investigated the phosphorothioate modifications in the cap triphosphate bridge (i.e., one of nonbridging phosphate oxygens replaced by sulfur). This is considered to be an almost perfect mimic of the phosphate moiety since it is isosteric, pseudoisoelectronic, and has a similar charge distibution and similar net charge at physiological $\mathrm{pH}$ (Eckstein 1985). Furthermore, phosphorothioate nucleotide analogs are often resistant to enzymatic cleavage and have been used as nonhydrolyzable substrate analogs.

\section{RESULTS}

We prepared a series of six novel phosphorothioate mRNA cap analogs ("S analogs") bearing a single phosphorothioate moiety at either the $\alpha, \beta$, or $\gamma$ positions of the triphosphate 
chain (Fig. 1). Due to the presence of a stereogenic P center, each $S$ analog was obtained as a mixture of two diastereomers, designated D1 and D2 according to their elution order during reverse phase (RP) HPLC. Each S analog was successfully resolved by RP HPLC, providing 12 compounds that subsequently were characterized biophysically and biochemically. Six of the $S$ analogs contained an ARCA modification, a 2'-O-methyl group in the $\mathrm{m}^{7}$ Guo moiety, and hence, are termed S-ARCAs. mRNAs capped with S-ARCAs have been characterized with respect to enzymatic susceptibility to hDcp2 in vitro and both translational efficiency and stability in cultured cells (Grudzien-Nogalska et al. 2007). Notably, introduction of a phosphorothioate group at the $\beta$ position produced resistance to Dcp2, increased half-life, and improved translational efficiency.

\section{Synthesis of $\mathrm{S}$ analogs}

The approach most commonly reported for the formation of a mixed phosphate-phosphorothioate anhydride bond has been coupling by the Michelson procedure employing diphenylphosphoryl chloride as an activating reagent (Eckstein and Goody 1976; Richard and Frey 1982). Although

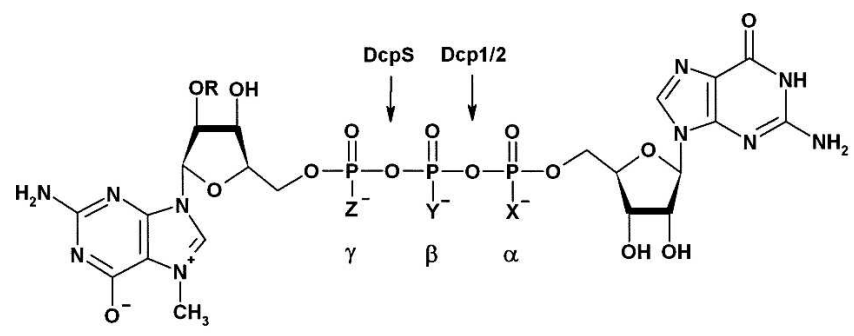

\begin{tabular}{|c|c|c|c|c|c|c|}
\hline Compound & Abbreviation & $x$ & $\mathbf{Y}$ & z & $\mathbf{R}$ & Configuration \\
\hline $1 \mathrm{a}$ & $m^{7} G p p p_{s} G(D 1)$ & $\mathbf{s}$ & 0 & 0 & H & $s_{p}$ \\
\hline $1 b$ & $m^{7} G p p p_{s} G(D 2)$ & s & 0 & o & H & $R_{P}$ \\
\hline $2 a$ & $m^{7} G p p_{s} p G(D 1)$ & 0 & $\mathbf{s}$ & o & H & n.a. \\
\hline 2b & $m^{7} G p p_{s} p G(D 2)$ & 0 & s & 0 & H & n.a. \\
\hline $3 a$ & $m^{7} G p_{s} p p G(D 1)$ & 0 & 0 & $\mathbf{s}$ & H & n.a. \\
\hline $\mathbf{3 b}$ & $m^{7} G p_{s} p p G(D 2)$ & 0 & 0 & $\mathbf{s}$ & H & n.a. \\
\hline $4 a$ & $\mathrm{~m}_{2}{ }^{7,2-0} \mathrm{Gppp}_{\mathrm{s}} \mathrm{G}$ (D1) & $\mathbf{s}$ & 0 & 0 & $\mathrm{CH}_{3}$ & $s_{p}$ \\
\hline 4b & $\mathrm{m}_{2}{ }^{7,2^{2}-0} \mathrm{Gppp} \mathrm{s}_{\mathrm{g}} \mathrm{G}$ (D2) & $\mathbf{s}$ & 0 & o & $\mathrm{CH}_{3}$ & $\boldsymbol{R}_{P}$ \\
\hline $5 \mathbf{a}$ & $\mathrm{m}_{2}{ }^{7,2-0} \mathrm{Gpp} p_{\mathrm{s}} \mathrm{pG}$ (D1) & 0 & s & o & $\mathrm{CH}_{3}$ & n.a. \\
\hline $5 \mathbf{b}$ & $m_{2}^{7,2-\circ} \mathrm{Gpp}_{\mathrm{s}} \mathrm{pG}(\mathrm{D} 2)$ & 0 & $\mathbf{s}$ & o & $\mathrm{CH}_{3}$ & n.a. \\
\hline $6 \mathbf{a}$ & $\mathrm{m}_{2}^{7,2-0} \mathrm{G} p_{s} p p G(D 1)$ & 0 & 0 & $\mathbf{s}$ & $\mathrm{CH}_{3}$ & n.a. \\
\hline $6 b$ & $m_{2}^{7,2-\circ} G p_{s} p p G(D 2)$ & 0 & 0 & $\mathbf{s}$ & $\mathrm{CH}_{3}$ & n.a. \\
\hline
\end{tabular}

FIGURE 1. Structures of the phosphorothioate cap analogs synthesized in this study. The respective DcpS and Dcp1/Dcp2 cleavage sites in the cap structure are marked together with $\alpha / \beta / \gamma$ phosphate designations. this reaction is applicable for the synthesis of dinucleoside $5^{\prime}, 5^{\prime}$-triphosphates, it has several features disadvantageous for phosphorothioate cap analog syntheses. The main difficulties would be poor solubility and stability of $\mathrm{m}^{7} \mathrm{Guo}$ containing nucleotides in dimethyl formamide (DMF)/ pyridine reaction mixtures. Also, low yields have been reported for analogs modified at the $\beta$ position of the triphosphate chain due to instability of nucleoside $5^{\prime}-\mathrm{O}-(2-$ thiodiphosphates) in pyridine (Eckstein and Goody 1976; Ho and Frey 1984). Therefore, we attempted chemical synthesis of $\mathrm{S}$ analogs by a strategy similar to that originally developed for the analogs not modified in the $5^{\prime}, 5^{\prime}$ polyphosphate bridge. In this strategy, two mononucleotide species, one of which has been previously converted to a reactive imidazolide derivative, are coupled in DMF. The reaction is mediated by excess $\mathrm{ZnCl}_{2}$, which significantly improves the solubility of reactants in organic media, prevents the hydrolysis of imidazolide derivatives, and accelerates the reaction rate (Kadokura et al. 1997; Stepinski et al. 2001). In the final step of each synthesis leading to a particular $S$ analog, a nucleotide imidazolide derivative was coupled to either a nucleoside $5^{\prime}$-thiophosphate or $5^{\prime}$-(2thiodiphosphate) in DMF in the presence of an excess of $\mathrm{ZnCl}_{2}$.

The synthetic pathway leading to analogs $\mathbf{1}$ and $\mathbf{4}$ modified at the $\alpha$ position of the $5^{\prime}, 5^{\prime}$-triphosphate bridge (i.e., $\mathrm{m}^{7} \mathrm{Gppp} \mathrm{s}_{\mathrm{S}} \mathrm{G}$ and $\mathrm{m}_{2}{ }^{7,2^{\prime}-O} \mathrm{Gppp}_{\mathrm{S}} \mathrm{G}$ ) is depicted in Figure 2. In both final coupling reactions, a 1.5- to twofold excess of phosphorimidazolide was used to ensure complete consumption of the nucleoside 5'-thiophosphate. The coupling proceeded steadily, leading to almost complete consumption of the substrate within 1-2 d. The synthesis of analogs 3 and 6 modified at the $\gamma$ position (i.e., $m^{7} G p_{s} p p G$ and $\mathrm{m}_{2}{ }^{7,2^{\prime}-O} \mathrm{Gp}_{\mathrm{spp}}$ ), which is depicted in Figure 3, was similar to the one described above. In each case, formation of two diastereomers was indicated by RP HPLC, as shown in Figure 4. The intermediate nucleoside $5^{\prime}$-thiophosphates 9-11 were synthesized via thiophosphorylation of appropriate nucleosides by $\mathrm{PSCl}_{3}$ in trimethyl phosphate in the presence of 2,6-dimethylpirydine at $0^{\circ} \mathrm{C}$, similar to the previously reported procedures (Moran and Whitesides 1984). In the case of compounds 10 and 11, the methylation at the N7 position had to be performed at the nucleoside stage, before the thiophosphorylation step; otherwise, methyl iodide preferably alkylates the sulfur atom (data not shown). Conversion of nucleoside 5 '-diphosphates into their imidazolide derivatives (7, 8, and 12-15) was easily achieved via reaction with imidazole employing the 2,2'-dithiodipyridine/triphenylphosphine activation system (Mukaiyama and Hashimoto 1971). The analogs modified at the $\beta$ position, i.e., $\mathrm{m}^{7} \mathrm{Gpp} \mathrm{spG}$ (2) and $\mathrm{m}_{2}{ }^{7,2^{\prime}-O} \mathrm{Gpp}_{\mathrm{spG}}$ (5), were synthesized as depicted in Figure 5. HPLC analysis of the final coupling revealed formation of two $\mathrm{P}$ diastereoisomers. However, their retention times were very similar. To obtain the intermediate nucleoside 


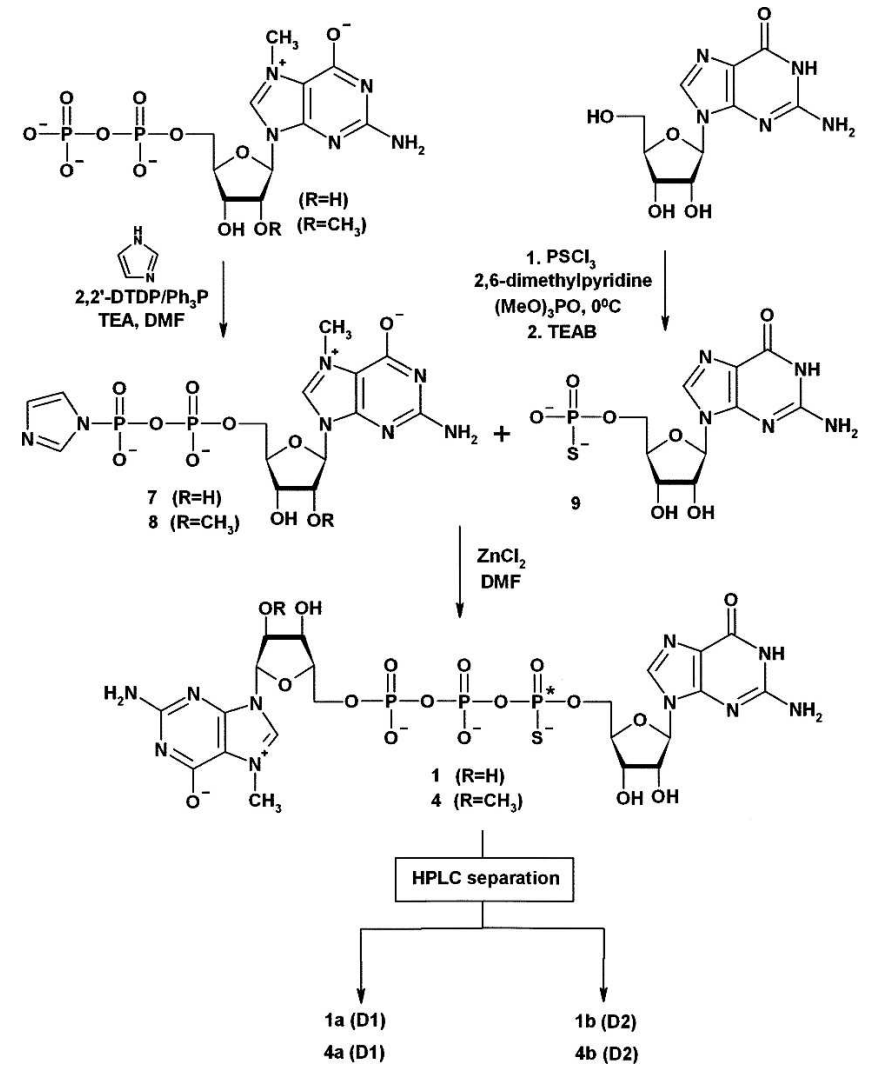

FIGURE 2. Synthesis of cap analogs modified at the $\alpha$ position of the $5^{\prime}, 5^{\prime}$-triphosphate bridge (compounds 1 and 4 ).

$5 '$-O-(2-thiodiphosphates) 16 and $\mathbf{1 7}$, we employed a recently developed coupling reaction between a nucleoside 5 '-monophosphate imidazolide and thiophosphate $\left(\mathrm{PSO}_{3}{ }^{3-}\right)$ triethylammonium salt as a nucleophile (Kowalska et al. 2007).

In all reactions leading to cap analogs 1-6, HLPC analysis revealed that the desired compounds were formed as the major products, with only moderate amounts of byproducts. Nonetheless, preparative yields were surprisingly lower than those indicated by HPLC, being in the range of $10 \%-20 \%$ overall. This is probably due to large losses of material during lengthy separation of diastereoisomers by RP HPLC, which in many cases was performed repeatedly in order to obtain diastereomerically pure samples.

\section{Binding affinities for elF4E}

We determined the binding affinities of $\mathrm{S}$ analogs for murine eIF4E by fluorescence quenching (Fig. 6). The descending titration curves arise from the quenching of intrinsic Trp fluorescence in eIF4E upon cap binding, whereas the increasing fluorescence signals after reaching the plateau originate from fluorescence emission of unbound cap analog. The $K_{\mathrm{AS}}$ values and free energies of binding $\left(\Delta G^{\circ}\right)$ of the $S$ analogs are presented in Table 1, together with the same data for their unmodified parent compounds. Surprisingly, the presence of the phosphorothioate moiety does not reduce binding affinity for eIF4E, instead in most cases it significantly increases it. The $K_{\mathrm{AS}}$ values are strongly dependent both on the position of the phosphorothioate modification and on the absolute configuration of the asymmetric $\mathrm{P}$ center. Interestingly, in each pair of diastereomers, the D1 member binds to eIF4E with an affinity that is 2.3- to 4.5-fold higher than the D2 member or the parent analog (Fig. 7). For instance, $K_{\mathrm{AS}}$ for the D1 isomer of $m^{7} G p_{s} p p G$ is threefold higher than for D2 or $\mathrm{m}^{7} \mathrm{GpppG}$. Similarly, $K_{\mathrm{AS}}$ for the D1 isomer of $\mathrm{m}^{7} \mathrm{Gpp}$ spG, is twofold higher than for D2 and 4.5-fold higher than for $\mathrm{m}^{7} \mathrm{GpppG}$. The S-ARCA series shows similar corresponding differences. The greatest differences in binding affinities between the D1/D2 diastereomers were observed for the $\gamma$-modified analogs, whereas the greatest differences between modified and unmodified pairs were observed for $\beta$-substituted analogs.

\section{Susceptibility to enzymatic hydrolysis by DcpS}

We subjected the new series of $S$ analogs to in vitro enzymatic hydrolysis catalyzed by DcpS from both human and Caenorhabditis elegans sources. In all experiments, the

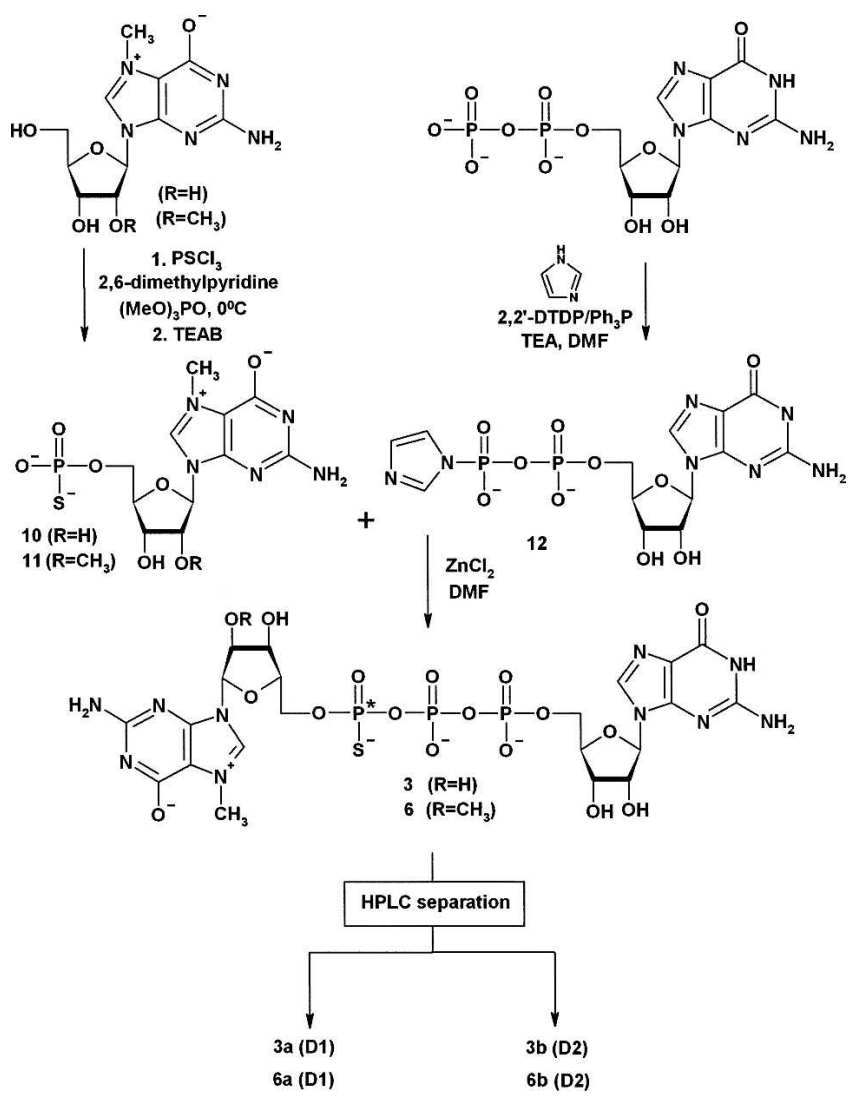

FIGURE 3. Synthesis of cap analogs modified at the $\gamma$ position of the $5^{\prime}, 5^{\prime}$-triphosphate bridge (compounds 3 and $\mathbf{6}$ ). 


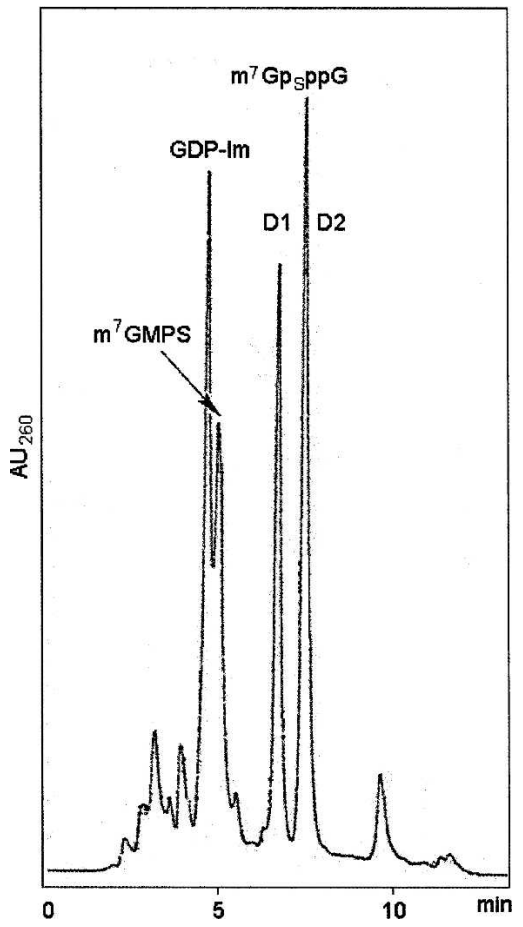

FIGURE 4. RP HPLC profile of coupling reaction between 7methylguanosine $5^{\prime}$-O-thiophosphate ( $\left.\mathrm{m}^{7} \mathrm{GMPS}\right)$ and guanosine $5^{\prime}$ $O$-diphosphate imidazolide derivative (GDP-Im) leading to two diastereomers of $\mathrm{m}^{7} \mathrm{Gp}_{\mathrm{s}} \mathrm{ppG}$ (3a and $\mathbf{3 b}$ ) marked D1 and D2 according to their elution order.

corresponding unmodified cap analog was used as a positive control, i.e., $\mathrm{m}^{7} \mathrm{GpppG}$ for non-ARCA $S$ analogs and $\mathrm{m}_{2}{ }^{7,2^{\prime}-O}$ GpppG for S-ARCAs. The amount of DcpS enzyme was optimized to provide complete degradation of the control substrate within 40-90 min. The samples collected from reaction mixtures at various time intervals were analyzed by RP HPLC (as described in Materials and Methods). We found that $S$ analogs modified at the $\gamma$ position were resistant to hydrolysis, independent of the P-center absolute configuration (Table 2). Identical results were obtained with longer reaction times up to $24 \mathrm{~h}$, different concentrations of enzyme, and different reaction buffers. All other $\mathrm{S}$ analogs were hydrolyzed by $\mathrm{hDcpS}$ with efficiencies comparable to the unmodified parent analog. No significant differences were observed for S-analog hydrolysis by DcpS from human and C. elegans sources.

Analysis of the DcpS degradation products of analogs modified at the $\alpha$ position allowed us to determine their absolute configuration of the asymmetric $\mathrm{P}$ centers. We found that hydrolysis of either $\mathrm{m}^{7} \mathrm{Gppp}_{\mathrm{S}} \mathrm{G}$ (D1) or $m^{7} \operatorname{Gppp}_{\mathrm{s}} \mathrm{G}$ (D2) by DcpS leads to $\mathrm{m}^{7} \mathrm{GMP}$ and either the $\mathrm{D} 1$ or D2 isomer of guanosine $5^{\prime}$-O-(1-thiodiphosphate) $(\mathrm{GDP} \alpha \mathrm{S})$, whereas hydrolysis of either $\mathrm{m}_{2}{ }^{7,2^{\prime}-\mathrm{O}} \mathrm{Gppp} \mathrm{s}_{\mathrm{S}} \mathrm{G}$ (D1) or $\mathrm{m}_{2}{ }^{7,2^{\prime}-O} \mathrm{Gppp}_{\mathrm{S}} \mathrm{G}$ (D2) leads to $\mathrm{m}_{2}{ }^{7,2^{\prime}-O} \mathrm{GMP}$ and either the D1 or D2 isomer of GDP $\alpha$ S (Fig. 8). The absolute configuration of $\mathrm{GDP} \alpha \mathrm{S}$ diastereomers is known-the isomer D1, which elutes earlier on RP HPLC, has been assigned the $S_{P}$ configuration (Connolly et al. 1982). Since there is no possibility of configurational change at the $\alpha$-phosphorus atom during the enzymatic hydrolysis, we thereby assigned the configuration of $m^{7} \mathrm{Gppp}_{\mathrm{s}} \mathrm{G}(\mathrm{D} 1)$ and $\mathrm{m}_{2}{ }^{7,2^{\prime}-O} \mathrm{Gppp}_{\mathrm{S}} \mathrm{G}(\mathrm{D} 1)$ as $S_{P}$.

\section{DcpS-resistant cap analogs as inhibitors of cap-dependent translation}

The ability of the new $S$ analogs to inhibit cap-dependent translation was assayed in a rabbit reticulocyte lysate system programmed with natural rabbit globin mRNA. Of the $12 \mathrm{~S}$ analogs, we selected two that were modified at the $\gamma$ position, $\mathrm{m}^{7} \mathrm{G} \mathrm{p}_{\mathrm{s}} \mathrm{ppG}(\mathrm{D} 1)$ and $\mathrm{m}^{7} \mathrm{G} \mathrm{p}_{\mathrm{s}} \mathrm{ppG}(\mathrm{D} 2)$, since they were found to be resistant toward DcpS and thus are potentially more stable in vivo. Representative data for the two $\mathrm{S}$ analogs and the unmodified parent compound, $\mathrm{m}^{7} \mathrm{GpppG}$, are shown in Figure 9. Data for inhibition of translation were fit to a theoretical curve that describes capdependent translation as a function of a competitive inhibitor of mRNA binding (Cai et al. 1999). This allowed us to determine $K_{\mathrm{I}}$, the cap analog concentration at which cap-dependent translation is inhibited by $50 \%$ (Table 3 ). Both $\mathrm{S}$ analogs were found to be better inhibitors of

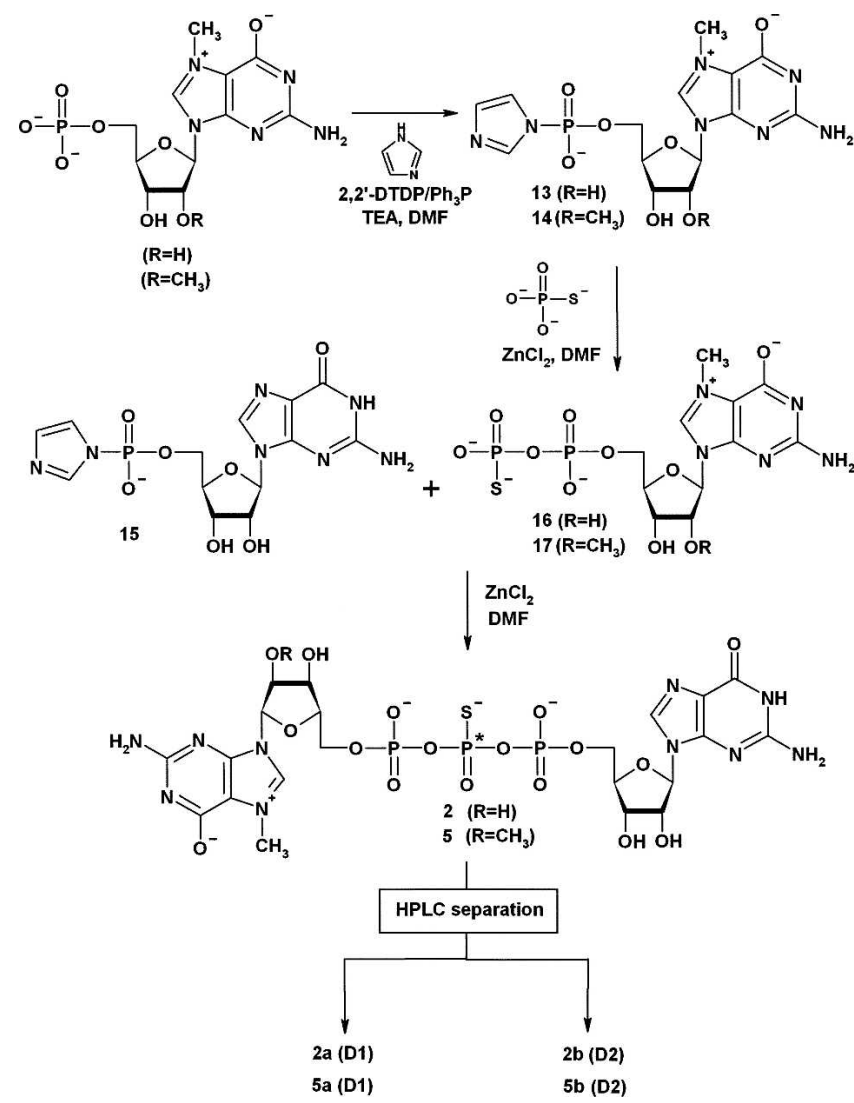

FIGURE 5. Synthesis of cap analogs modified at the $\beta$ position of the $5^{\prime}, 5^{\prime}$-triphosphate bridge (compounds 2 and 5 ). 


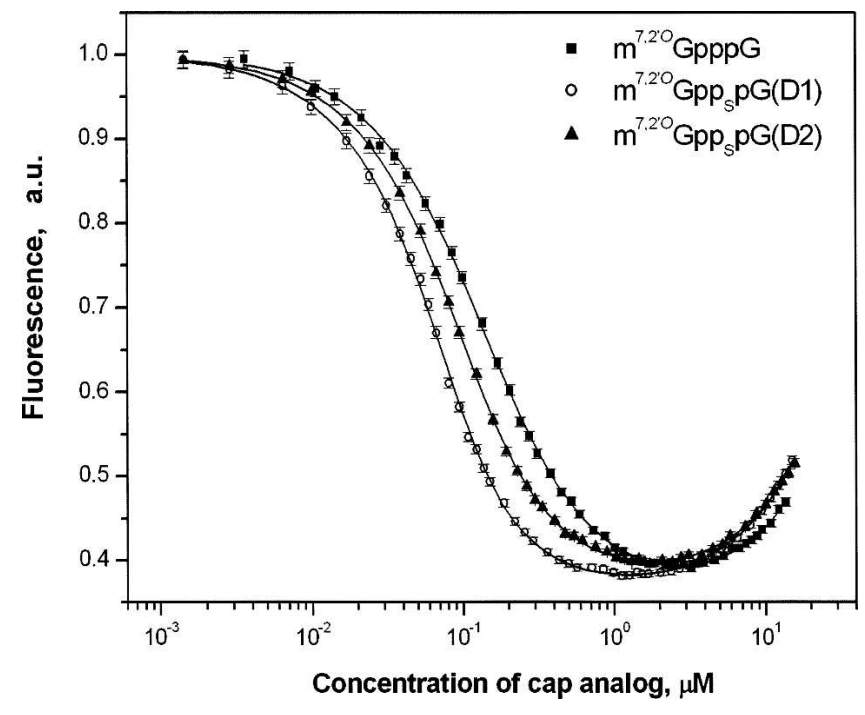

FIGURE 6. Fluorescence titration curves for binding of $\mathrm{m}^{7,2^{\prime}-\mathrm{O}} \mathrm{GpppG}$, $\mathrm{m}^{7,2^{\prime}-O} \mathrm{Gpp}$ spG (D1), and $\mathrm{m}^{7,2^{\prime}-O} \mathrm{Gpp}$ spG (D2) to mouse eIF4E (28-217). The observed shift of curves toward the higher ligand concentration indicated a weaker binding between eIF4E and the corresponding cap analog. The observed increasing fluorescence signal at a higher concentration of ligands originates from the emission of free cap analog in solution. The intensity of fluorescence is represented as relative values. (a.u.) Arbitrary units.

cap-dependent translation than $\mathrm{m}^{7} \mathrm{GpppG}$, which constitutes additional evidence that the phosphorothioate moiety generally strengthens the cap-eIF4E interaction. Moreover, $\mathrm{m}^{7} \mathrm{Gp}$ sppG (D1) was significantly more inhibitory than its D2 counterpart $\left(K_{\mathrm{I}}=4.1 \pm 0.2 \mu \mathrm{M}\right.$ versus $K_{\mathrm{I}}=12.1 \pm$ $3.2 \mu \mathrm{M}$ ), which is in agreement with its higher binding affinity for eIF4E based on fluorescent titration analyses $\left(K_{\mathrm{AS}}=30.8 \pm 0.5 \mu \mathrm{M}^{-1}\right.$ versus $\left.K_{\mathrm{AS}}=10.0 \pm 0.2 \mu \mathrm{M}^{-1}\right)$. resolve the P diastereomers by RP HPLC, which allowed us to use diastereomerically pure samples in the subsequent biophysical and biochemical studies.

The determination of the binding affinity for eIF4E (expressed as an association equilibrium constant, $K_{\mathrm{AS}}$ ) is a reliable biophysical test enabling one to predict the biochemical properties of newly synthesized cap analogs. Generally, higher $K_{\mathrm{AS}}$ values correlate positively with stronger inhibitory potential of the cap analog and higher translational efficiency when incorporated into mRNA. As mentioned in the Introduction, the methylenebisphosphonate modification of the triphosphate bridge reduced the affinity of cap analogs for eIF4E, which reduced the translational efficiency of mRNAs capped with these analogs (Grudzien et al. 2006). By contrast, the phosphorothioate modification present at any position of the triphosphate bridge does not diminish the cap-eIF4E interaction. The differences in binding affinity of different $\mathrm{S}$ analogs for eIF4E can be explained by the geometry of interactions within the cap-binding pocket (Fig. 10). The cap-eIF4E complex, besides the stacking of 7-methylguanine between Trp-56 and Trp-102, is stabilized by hydrogen bonds and salt bridges between the negatively charged triphosphate bridge and positively charged amino acid residues in the cap binding pocket. Biophysical studies of eIF4E binding with cap analogs have shown that the addition to $\mathrm{m}^{7}$ Guo of $\gamma, \beta$, and $\alpha$ phosphates results in a progressive increase in binding affinity for eIF4E, with corresponding energetic contributions $\left(\Delta \Delta G^{\circ}\right)$ of $\sim 3.0$, $\sim 1.9$, and $\sim 0.9 \mathrm{kcal} / \mathrm{mol}$, respectively (Niedzwiecka et al. 2002). This observation is in agreement with data from $\mathrm{X}$-ray crystal structures that reveal two salt bridges crucial for cap-eIF4E interaction, one between the nonbridging pro- $R_{P}$ oxygen at the $\gamma$ position and the guanidinium group of Arg-157, and another between the nonbridging

\section{DISCUSSION}

The series of new cap analogs 1-6 with phosphorothioate modifications within the triphosphate bridge is the next step in our search for cap analogs with increased resistance to enzymatic cleavage. Although the overall strategy for the multistep synthesis leading to $S$ analogs was similar to those reported previously (Stepinski et al. 2001; Jemielity et al. 2003), we demonstrated for the first time the use of nucleoside $5^{\prime}$-O-phosphorothioates and 5'-O-(2thiodiphosphates) as nucleophiles in $\mathrm{ZnCl}_{2}$-promoted coupling reactions with nucleotide imidazolide derivatives. The $\mathrm{S}$ analogs are also the first examples of P-chiral cap analogs. For each $\mathrm{S}$ analog we found conditions to
TABLE 1. Equilibrium association constants $\left(K_{\mathrm{AS}}\right)$ and binding free energies $\left(\Delta G^{\circ}\right)$ for the binding of murine elF4E (28-217) to phosphorothioate cap analogs, as determined by fluorescence quenching

\begin{tabular}{|c|c|c|c|}
\hline Compound & Cap analog & $K_{\mathrm{AS}}\left(\mu \mathrm{M}^{-1}\right)$ & $\Delta G^{\circ}(\mathrm{kcal} / \mathrm{mol})$ \\
\hline & $\mathrm{m}^{7} \mathrm{GpppG}$ & $9.4 \pm 0.4$ & $-9.35 \pm 0.02$ \\
\hline $1 \mathbf{a}$ & $\mathrm{m}^{7} \mathrm{Gppp} \mathrm{s}_{\mathrm{S}} \mathrm{G}(\mathrm{D} 1)$ & $23.6 \pm 0.8$ & $-9.88 \pm 0.02$ \\
\hline $1 \mathrm{~b}$ & $\mathrm{~m}^{7} \mathrm{Gppp} \mathrm{s}_{\mathrm{S}} \mathrm{G}(\mathrm{D} 2)$ & $13.1 \pm 0.8$ & $-9.54 \pm 0.03$ \\
\hline $2 a$ & $\mathrm{~m}^{7} \mathrm{GppspG}(\mathrm{D} 1)$ & $45.0 \pm 1.1$ & $-10.26 \pm 0.01$ \\
\hline $2 b$ & $\mathrm{~m}^{7} \mathrm{GppspG}(\mathrm{D} 2)$ & $23.0 \pm 0.4$ & $-9.87 \pm 0.01$ \\
\hline $3 \mathbf{a}$ & $\mathrm{m}^{7} \mathrm{GpsppG}(\mathrm{D} 1)$ & $30.8 \pm 0.5$ & $-10.04 \pm 0.01$ \\
\hline \multirow[t]{2}{*}{$3 \mathbf{b}$} & $\mathrm{m}^{7} \mathrm{GpsppG}(\mathrm{D} 2)$ & $10.0 \pm 0.2$ & $-9.39 \pm 0.01$ \\
\hline & $\mathrm{m}_{2}{ }^{7,2^{\prime}-\mathrm{O}} \mathrm{GpppG}$ & $10.8 \pm 0.3$ & $-9.43 \pm 0.02$ \\
\hline $4 a$ & $\mathrm{~m}_{2}^{7,2^{\prime}-O} \mathrm{Gppp}_{\mathrm{S}} \mathrm{G}(\mathrm{D} 1)$ & $19.2 \pm 0.8$ & $-9.76 \pm 0.03$ \\
\hline $4 b$ & $\mathrm{~m}_{2}{ }^{7,2^{\prime}-\mathrm{O}} \mathrm{Gppp} \mathrm{G}(\mathrm{D} 2)$ & $15.0 \pm 0.6$ & $-9.62 \pm 0.02$ \\
\hline $5 a$ & $\mathrm{~m}_{2}{ }^{7,2^{\prime}-O} \mathrm{Gpp}$ spG (D1) & $43.1 \pm 1.4$ & $-10.23 \pm 0.02$ \\
\hline $5 b$ & $\mathrm{~m}_{2}{ }^{7,2^{\prime}-O} \mathrm{Gpp}_{\mathrm{s}} \mathrm{pG}(\mathrm{D} 2)$ & $19.3 \pm 2.2$ & $-9.77 \pm 0.07$ \\
\hline $6 a$ & $\mathrm{~m}_{2}{ }^{7,2^{\prime}-O} \mathrm{Gp}$ sppG (D1) & $35.2 \pm 1.1$ & $-10.12 \pm 0.02$ \\
\hline $6 \mathbf{b}$ & $\mathrm{m}_{2}{ }^{7,2^{\prime}-O} \mathrm{Gp}$ sppG (D2) & $12.9 \pm 0.4$ & $-9.53 \pm 0.02$ \\
\hline
\end{tabular}




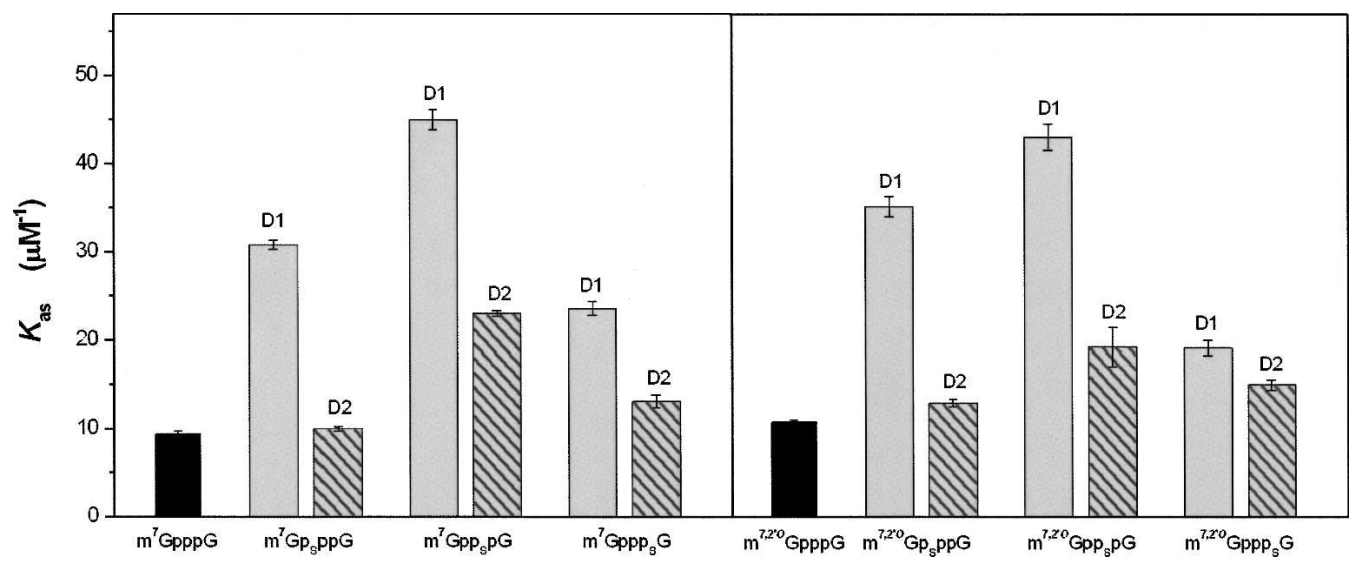

FIGURE 7. Comparison of association constants for complexes between eIF4E and the standard cap analog $\left(\mathrm{m}^{7} \mathrm{GpppG}\right)$ or cap $\mathrm{S}$ analogs. The influence of sulfur presence in the phosphate chain of the cap analog on its binding by eIF4E depends strongly on its position and the absolute configuration of asymmetric P centers.

pro- $R_{P}$ oxygen at the $\beta$ position and the ammonium group of Lys-162. Four other oxygens are involved in H-bond interactions, either directly or mediated by water molecules. These data are convergent with our finding that the largest increases in the binding affinity were observed for one of the diastereomers substituted at the $\gamma$ position and one substituted at the $\beta$-position $\left[\mathrm{m}^{7} \mathrm{Gp}\right.$ sppG (D1), 3a, and $\mathrm{m}^{7} \mathrm{Gpp}_{\mathrm{S}} \mathrm{pG}$ (D1), 2a; with corresponding observations in the S-ARCA series]. Based on known physicochemical properties of phosphorothioate anions, we propose that the effect of the oxygen-to-sulfur substitution results from increased polarizability of phosphorothioate in comparison to the phosphate group. It was previously suggested that binding of phosphorothioates at protein active sites containing ammonium and guanidinium moieties is more similar to crystalline phosphorothioate salts than to water-solvated species (Baraniak and Frey 1988). In phosphorothioate crystalline salts, positively charged countercations coordinate closely to oxygen, drawing the electron density from sulfur. This results in shortening of the $\mathrm{P}-\mathrm{S}$ bond and decreasing of the $\mathrm{P}-\mathrm{O}$ bond order (Saenger and Eckstein 1970), unlike water-solvated species where the P-S bond orders are close to one (Frey and Sammons 1985). Therefore, most likely the greatest increase in the binding affinity of eIF4E for phosphorothioate cap analogs is observed if the sulfur atom occupies either $\gamma$-pro- $S_{P}$ or $\beta$-pro- $S_{P}$ position in the triphosphate bridge, allowing a shift of the negative charge toward the respective pro- $R_{P}$ oxygen involved in the salt-bridge interaction. In this case, $\mathrm{m}^{7} \mathrm{Gp}$ sppG (D1) and $\mathrm{m}^{7} \mathrm{Gpp}$ spG (D1), as well as their ARCA counterparts, would have the $S_{P}$ configuration. However, our hypothesis cannot be properly verified without knowledge of the absolute configuration at the asymmetric $\mathrm{P}$ centers of the $\beta$ - and $\gamma$-substituted $S$ analogs. Unfortunately, we have been able to assign the absolute configuration only for the analogs substituted at the $\alpha$ position. However, our observation of the upfield shift of the $\mathrm{m}^{7}$ Guo
H8 proton in the ${ }^{1} \mathrm{H}$ NMR spectrum of $\mathrm{m}^{7} \mathrm{Gp}$ sppG (D1) and $\mathrm{m}_{2}{ }^{7,2^{\prime}-O} \mathrm{GpsppG}(\mathrm{D} 1)$, together with the previously reported correlation between the retention time on the RP HPLC column and the absolute configurations of nucleoside 5'-O-(1-thiotriphosphates) and 5'-O-(1-thiodiphosphates) (i.e., $S_{P}$ is the faster) (Ludwig and Eckstein 1989; Li et al. 2005), suggest that the D1 isomers are also of the $S_{P}$ configuration in the case of $\gamma$-substituted $S$ analogs.

TABLE 2. Susceptibility of $\mathrm{S}$ analogs to enzymatic hydrolysis by DcpS (from human and C. elegans) in vitro

\begin{tabular}{|c|c|c|}
\hline Compound & Cap analog & Reactivity \\
\hline & $\mathrm{m}^{7} \mathrm{GpppG}$ & Hydrolyzed \\
\hline $1 \mathrm{a}$ & $\mathrm{m}^{7} \mathrm{Gppp} \mathrm{s}_{\mathrm{S}} \mathrm{G}(\mathrm{D} 1)$ & Hydrolyzed \\
\hline $1 b$ & $\mathrm{~m}^{7} \mathrm{Gppp} \mathrm{s}_{\mathrm{S}} \mathrm{G}(\mathrm{D} 2)$ & Hydrolyzed \\
\hline $2 a$ & $\mathrm{~m}^{7} \mathrm{Gpp}$ s $\mathrm{g}(\mathrm{D} 1)$ & Hydrolyzed \\
\hline $2 b$ & $\mathrm{~m}^{7} \mathrm{Gpp} p_{\mathrm{s}} \mathrm{g}(\mathrm{D} 2)$ & Hydrolyzed \\
\hline $3 a$ & $\mathrm{~m}^{7} \mathrm{Gp} \mathrm{ppg}(\mathrm{D} 1)$ & Resistant \\
\hline \multirow[t]{2}{*}{$3 \mathbf{b}$} & $\mathrm{m}^{7} \mathrm{GpsppG}(\mathrm{D} 2)$ & Resistant \\
\hline & $\mathrm{m}_{2}{ }^{7,2^{\prime}-O} \mathrm{GpppG}$ & Hydrolyzed \\
\hline $4 \mathbf{a}$ & $\mathrm{m}_{2}{ }^{7,2^{\prime}-O} \mathrm{Gppp}_{\mathrm{S}} \mathrm{G}(\mathrm{D} 1)$ & Hydrolyzed \\
\hline $4 b$ & $\mathrm{~m}_{2}{ }^{7,2^{\prime}-O} \mathrm{Gppp}_{\mathrm{S}} \mathrm{G}(\mathrm{D} 2)$ & Hydrolyzed \\
\hline $5 \mathbf{a}$ & $\mathrm{m}_{2}^{7,2^{\prime}-O} \mathrm{Gpp}$ spG (D1) & Hydrolyzed \\
\hline $5 b$ & $\mathrm{~m}_{2}{ }^{7,2^{\prime}-O} \mathrm{Gpp}$ spG (D2) & Hydrolyzed \\
\hline $6 a$ & $\mathrm{~m}_{2}{ }^{7,2^{\prime}-O} \mathrm{Gp}$ sppG (D1) & Resistant \\
\hline $6 b$ & $\mathrm{~m}_{2}{ }^{7,2^{\prime}-O} \mathrm{Gp}$ sppG (D2) & Resistant \\
\hline
\end{tabular}

Cap analogs at $4 \mu \mathrm{M}$ concentration were subjected to enzymatic digestion by $\mathrm{DcpS}$ in conditions leading to complete degradation of the unmodified parent compound (i.e., $\mathrm{m}^{7} \mathrm{GpppG}$ for non-ARCA $\mathrm{S}$ analogs and $\mathrm{m}_{2}{ }^{7,2^{\prime}-O} \mathrm{GpppG}$ for ARCAs) within 40-90 min. Samples collected from reaction mixtures at various time intervals were analyzed by RP HPLC with UV detection at $260 \mathrm{~nm}$ as described in the Materials and Methods. The analogs assigned as resistant remained completely undigested under the applied conditions, whereas the analogs assigned as hydrolyzed were hydrolyzed by DcpS with efficiency comparable to the respective unmodified parent compound. 

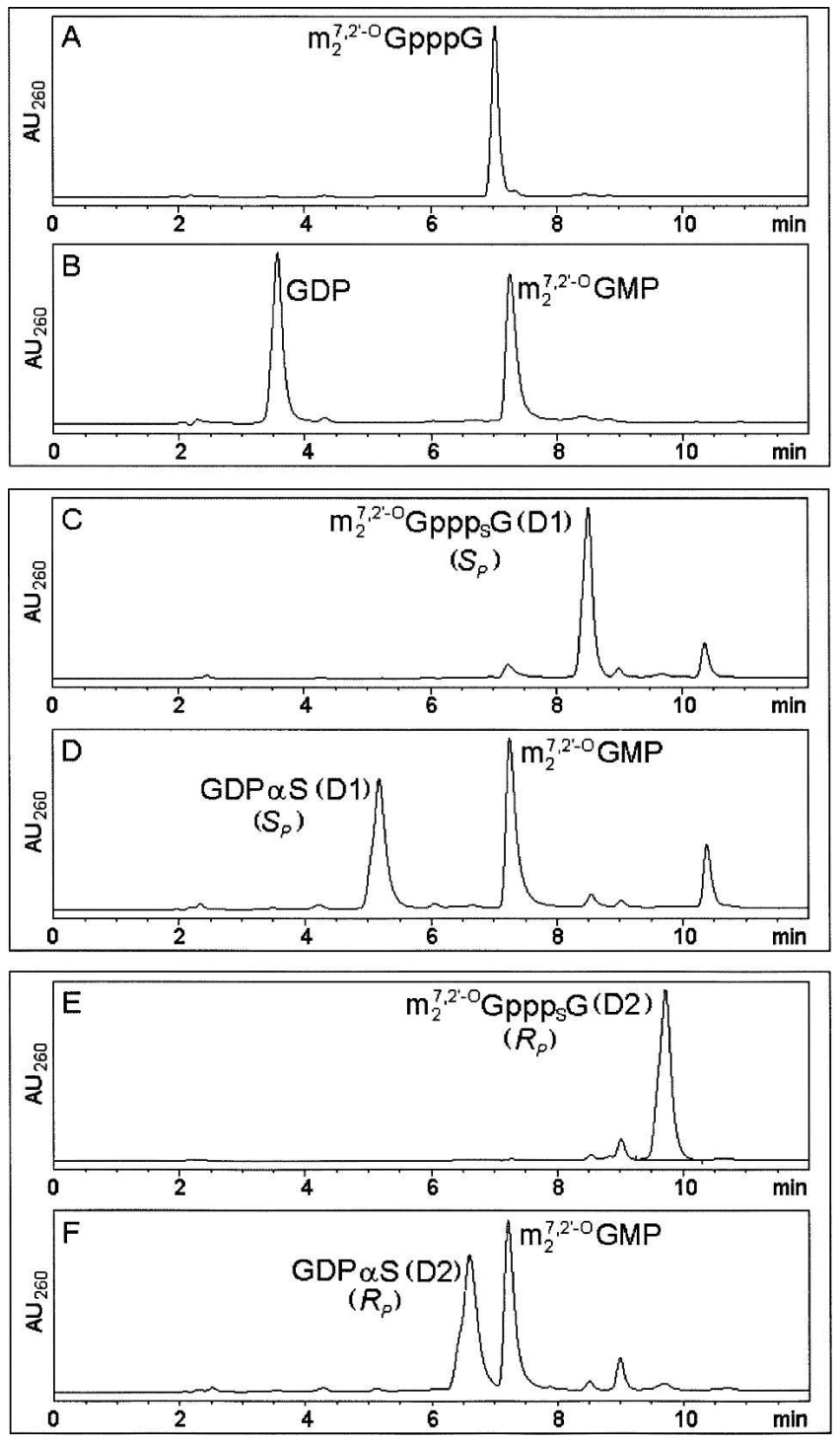

FIGURE 8. Correlation of the absolute configuration of D1 and D2 isomers of $\mathrm{m}_{2}^{7,2^{\prime}-O} \mathrm{Gppp}_{\mathrm{S}} \mathrm{G}$ (compounds $4 \mathbf{a}$ and $\mathbf{4 b}$ ) with $S_{P}$ and $R_{P}$ diastereomers of guanosine $5^{\prime}$-O-(2-thiodiphosphate) (GDP $\left.\alpha \mathrm{S}\right)$. The RP HPLC analysis shows that unmodified ARCA analog $\mathrm{m}_{2}{ }^{7,2^{\prime}-\mathrm{O}} \mathrm{GpppG}$ $(A)$ is hydrolyzed by DcpS to $\mathrm{m}_{2}{ }^{7,2^{\prime}-O} \mathrm{GMP}$ and GDP $(B)$. The D1 isomer of $\mathrm{m}_{2}{ }^{7,2^{\prime}-O} \mathrm{Gppp}_{\mathrm{s}} \mathrm{G}(C)$ is hydrolyzed by DcpS to $\mathrm{m}_{2}{ }^{7,2^{\prime}-\mathrm{O}} \mathrm{GMP}$ and the D1 isomer of $\mathrm{GDP} \alpha \mathrm{S}(D)$, whereas the D2 isomer of $\mathrm{m}_{2}{ }^{7,2^{\prime}-O} \mathrm{Gppp}_{\mathrm{S}} \mathrm{G}(E)$ is hydrolyzed by DcpS to $\mathrm{m}_{2}{ }^{7,2^{\prime}-\mathrm{O}} \mathrm{GMP}$ and the $\mathrm{D} 2$ isomer of $\mathrm{GDP} \alpha \mathrm{S}(F)$. The absolute configuration of the D1 and $\mathrm{D} 2$ isomers of GDP $\alpha \mathrm{S}$ was assigned previously as $S_{P}$ and $R_{P}$, respectively.

As determined by in vitro enzymatic hydrolysis experiments, the resistance to DcpS was observed only for the $S$ analogs modified at the $\gamma$ position. This is the position that is directly involved in the catalytic mechanism. DcpS, as a member of the HIT family of pyrophosphatases, employs a histidine triad motif to carry out the hydrolysis (Liu et al. 2002). The hDcpS catalysis proceeds by the nucleophilic attack of the His 277 imidazole ring on the cap $\gamma$ phosphate
( $\mathrm{Gu}$ et al. 2004), and the mechanism presumably involves a trigonal-bipyramidal pentacoordinated transition state (Lima et al. 1997). Since the DcpS cap-binding pocket is relatively tight, the resistance of the $\gamma$-substituted $S$ analogs to DcpS is likely due to steric bulk of the sulfur atom in comparison to oxygen, hindering the course of nucleophilic substitution. Although it was previously found that DcpS orthologs from human and C. elegans differ in their substrate specificity (C. elegans, but not human, DcpS can hydrolyze $\mathrm{m}_{3}{ }^{2,2,7} \mathrm{GpppG}$ cap and requires shorter capped oligoncleotides as a substrate) (Cohen et al. 2004), we have not found any significant differences in their ability to hydrolyze $\mathrm{S}$ analogs, indicating that the general catalytic mechanism for these two enzymes is similar.

The finding that both DcpS-resistant $S$ analogs, $\mathrm{m}^{7} \mathrm{G} \mathrm{p}_{\mathrm{spp}} \mathrm{G}$ (D1) and (D2), inhibit cap-dependent translation in vitro more effectively than $\mathrm{m}^{7} \mathrm{GpppG}$ contributes additional evidence that the phosphorothioate moiety does not disturb, but rather increases, the strength of the capeIF4E interaction. The differences in $K_{\mathrm{I}}$ between the diastereomers were in qualitative correlation with their binding affinities for eIF4E (Table 3). Notably, the $K_{\mathrm{I}}$ value for $\mathrm{m}^{7} \mathrm{GpsppG}$ (D1) is comparable to that of $\mathrm{m}^{7} \mathrm{GTP}$ $\left(K_{\mathrm{I}}=4.4 \mu \mathrm{M}\right) \quad$ (Cai et al. 1999), which makes it by far the most inhibitory dinucleoside triphosphate analog developed to date.

The substrate specificity of DcpS suggests that the major role of this enzyme is removal of mRNA degradation products, which could interact with cap-binding proteins, interfering with crucial cellular processes and thus becoming toxic to the cell. In this respect, DcpS activity poses a putative threat to synthetic cap analogs destined for studies

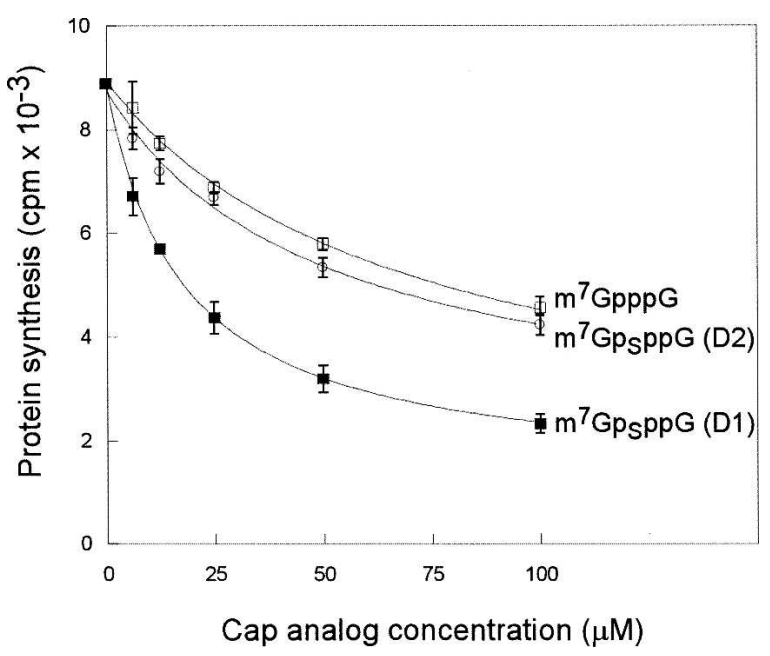

FIGURE 9. Inhibition of globin mRNA translation in rabbit reticulocyte lysate by $\mathrm{m}^{7} \mathrm{GpppG}(\square), \mathrm{m}^{7} \mathrm{Gp}$ sppG (D1) (ם), and $\mathrm{m}^{7} \mathrm{Gp}$ sppG (D2) (O). Natural rabbit globin mRNA was translated at $5 \mu \mathrm{g} / \mathrm{mL}$ in a rabbit reticulocyte lysate system, and globin synthesis was detected by incorporation of $\left[{ }^{3} \mathrm{H}\right]$ Leu into protein as described in the Materials and Methods. 
TABLE 3. Inhibitory constants $\left(K_{\mathrm{l}}\right)$ for inhibition of cap-dependent translation by $\gamma$-modified S- analogs in a rabbit reticulocyte lysate translation system

\begin{tabular}{llr}
\hline Compound & \multicolumn{1}{c}{ Cap analog } & \multicolumn{1}{c}{$\mathrm{K}_{\mathrm{i}}[\mathrm{uM}]$} \\
\hline & $\mathrm{m}^{7} \mathrm{GpppG}$ & $17.1 \pm 2.5$ \\
3a & $\mathrm{m}^{7} \mathrm{Gp}$ sppG (D1) & $4.1 \pm 0.2$ \\
3b & $\mathrm{m}^{7} \mathrm{G}$ sppG (D2) & $12.1 \pm 3.2$ \\
\hline
\end{tabular}

in vivo, e.g., those with potential therapeutic value. Many studies have shown that eIF4E is an attractive target for anti-cancer directed therapy. The ability of cap analogs to inhibit translation in vitro suggests that highly specific cap analog inhibitors of eIF4E might counteract elevated eIF4E levels in tumor cells. However, the inhibition of cap-dependent translation by cap analogs in vivo has not yet been demonstrated, mainly because such an application requires that cap analogs not only have strong inhibitory potency but also retain sufficiently high stability. One of our motivations for modifying the $5^{\prime}, 5^{\prime}$-phosphate bridge was to produce a cap analog resistant to DcpS hydrolysis that would inhibit translation through its interaction with eIF4E. The two DcpS-resistant $S$ analogs, $\mathrm{m}^{7} \mathrm{Gp}$ sppG (D1) and (D2), offer a promising new solution to this problem.

Whereas DcpS is responsible for degradation of free cap structures and capped mRNA degradation products, the decapping and thus degradation of intact mRNAs is dependent on Dcpl/ Dcp2 activity. Protecting mRNA from Dcp2 cleavage by introducing an appropriately chemically modified cap analog at its $5^{\prime}$-end should produce transcripts with increased stability. In a related study (Grudzien-Nogalska et al. 2007), we demonstrated that phosphorothioate modification at the $\beta$ position protects mRNAs against Dcp2 in vitro. This results in prolonged half-lives and higher translational efficiencies of such mRNAs in cultured mammalian cells. The ability to produce more stable mRNAs with higher translational efficiency can be advantageous for applications exploiting the concept of RNA-based gene delivery. For instance, transfection with
mRNAs encoding tumor-associated antigens is a promising approach to cancer therapy by autoimmunization with a patient's own dendritic cells (Mitchell and Nair 2000). Recently, it was demonstrated that ARCA-mRNA capping remarkably increased the expression level of reporter protein in mouse dendritic cells (Mockey et al. 2006).

In addition, the analogs we have developed that are resistant to enzymatic cleavage should be useful for biophysical, biochemical, and structural studies (e.g., NMR or X-ray crystallography) to provide new insights into the catalytic mechanism(s) of decapping enzymes and their regulation. The ability to obtain each $\mathrm{S}$ analog as diastereomerically pure populations offers the possibility of exploiting them as P-chiral probes useful for the elucidation of the stereochemical course of enzymatic processes involving cap as well as mapping of the active sites of cap binding proteins.

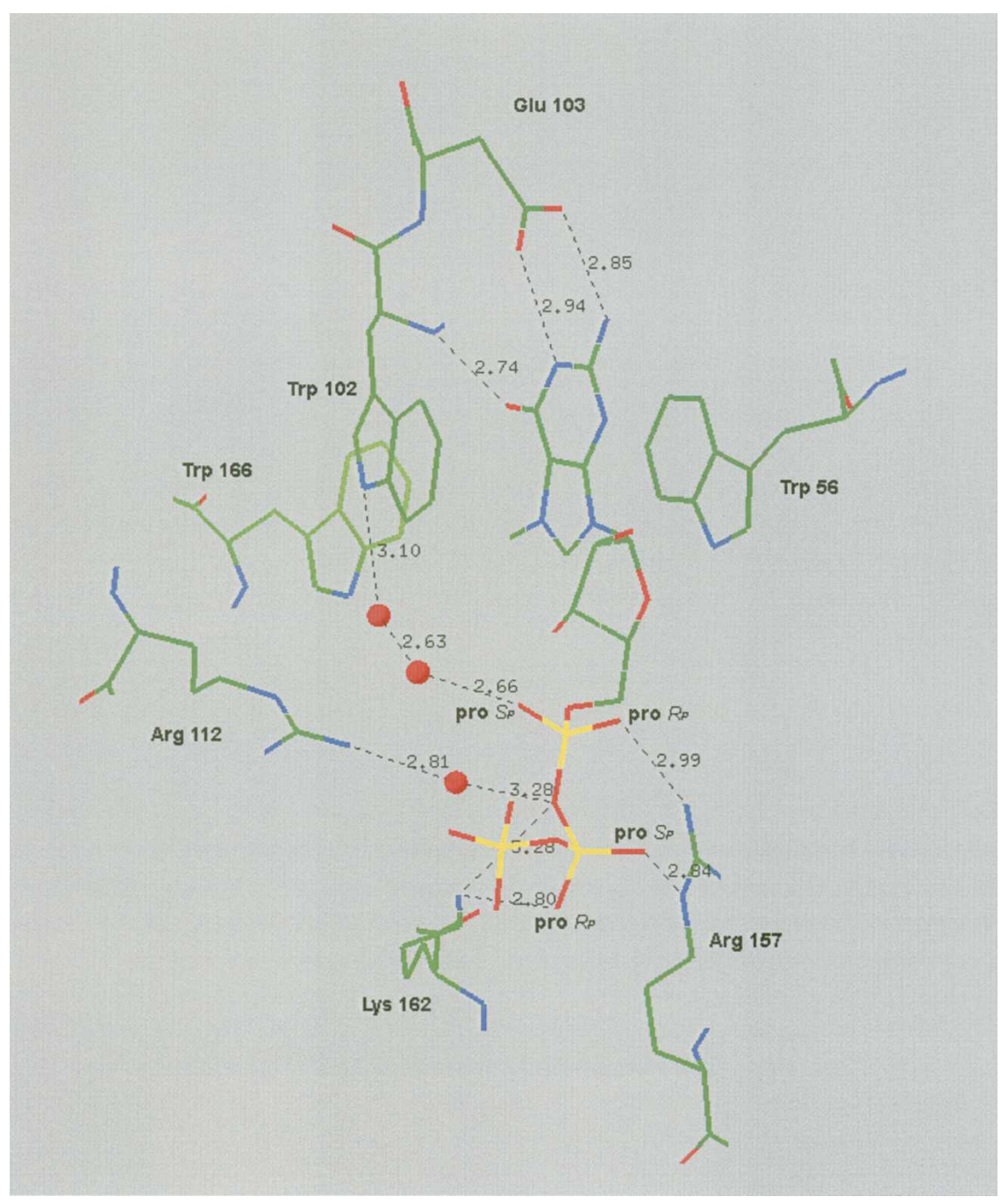

FIGURE 10. Interatomic contacts in the $\mathrm{m}^{7} \mathrm{GpppG}-$ mouse eIF4E (28-217) complex, determined on the basis of the crystallographic structure (PDB entry 1L8B). The possible interactions are shown by dotted lines, and their lengths are expressed in $\AA$. (Green) Carbon atoms, (blue) nitrogen, (yellow) phosphorus, (red) oxygen. 


\section{MATERIALS AND METHODS}

Intermediate nucleotides were separated by ion-exchange chromatography on a DEAE-Sephadex A-25 $\left(\mathrm{HCO}^{3-}\right.$ form) column using a linear gradient of triethylammonium bicarbonate (TEAB) in deionized water and, after evaporation under reduced pressure with addition of ethanol, were isolated as triethylammonium salts. Final products (cap analogs) were separated by either analytical or semipreparative RP HPLC and, after repeated freeze-drying, were isolated as ammonium salts. Analytical HPLC was performed on a Spectra-Physics SP8800 apparatus, using a Supelcosil LC-18-T RP column $(4.6 \times 250 \mathrm{~mm}$, flow rate $1.3 \mathrm{~mL} / \mathrm{min})$ with a linear gradient of $0 \%-25 \%$ methanol in $0.05 \mathrm{M}$ ammonium acetate buffer ( $\mathrm{pH}$ 5.9) and UV detection at $260 \mathrm{~nm}$. Semipreparative HPLC was performed on a Waters 600E Multisolvent Delivery System apparatus, using a Waters HR-C-18 reverse phase column $(19 \mathrm{~mm} \times 300 \mathrm{~mm}$, flow rate $5.0 \mathrm{~mL} / \mathrm{min}$ ) with a linear gradient of methanol in $0.05 \mathrm{M}$ ammonium acetate buffer ( $\mathrm{pH}$ 5.9) and UV detection at $260 \mathrm{~nm}$.

GMP and GDP were purchased from Sigma-Aldrich and converted into triethylammonium salts using Dowex 50 WX8 ion-exchange resin. Other nucleotides, i.e., $\mathrm{m}^{7} \mathrm{GMP}, \mathrm{m}_{2}{ }^{7,2^{\prime}-O} \mathrm{GMP}$, $\mathrm{m}^{7} \mathrm{GDP}$, and $\mathrm{m}_{2}{ }^{7,2^{\prime}-O} \mathrm{GDP}$, were prepared as previously reported (Darzynkiewicz et al. 1985; Jemielity et al. 2003). Thiophosphate triethylammonium salt was prepared from $\mathrm{Na}_{3} \mathrm{PSO}_{3}$ (Sigma) by conversion on Dowex 50 WX8 and, after evaporation to dryness and re-evaporation with $99.8 \%$ ethanol, was stored at $-20^{\circ} \mathrm{C}$ (Kowalska et al. 2007). 7-methylguanosine was prepared from guanosine by methylation with $\mathrm{CH}_{3} \mathrm{I}$ similarly to previously reported procedure (Jones and Robins 1963). 7,2'-O-dimethylguanosine was obtained similarly from 2'-O-methylguanosine (Kusmierek and Shugar 1978).

The structure and homogeneity of each final product was confirmed by re-chromatography on RP HPLC, mass spectrometry using negative electrospray ionization (MS ESI-), and ${ }^{1} \mathrm{H}$ NMR and ${ }^{31} \mathrm{P}$ NMR spectroscopy (Table 4). ${ }^{1} \mathrm{H}$ NMR and ${ }^{31} \mathrm{P}$ NMR spectra were recorded at $25^{\circ} \mathrm{C}$ on a Varian UNITY-plus spectrometer at $399.94 \mathrm{MHz}$ and $161.90 \mathrm{MHz}$, respectively. ${ }^{1} \mathrm{H}$ NMR chemical shifts were reported to sodium 3-trimethylsilyl[2,2,3,3-D4]-propionate (TSP) in $\mathrm{D}_{2} \mathrm{O}$ as an internal standard. ${ }^{31} \mathrm{P}$ NMR chemical shifts were reported to $20 \%$ phosphorus acid in $\mathrm{D}_{2} \mathrm{O}$ as an external standard. Mass spectra were recorded on a Micromass QToF 1 MS spectrometer.

\section{General procedure for nucleotide imidazolide derivatives $(7,8$, and $12-15)$}

An appropriate nucleotide (1 eq., TEA salt), imidazole (8 eq.), and 2,2'-dithiodipyridine (3 eq.) were mixed in DMF $(\sim 2.5 \mathrm{~mL} / 100$ mg of nucleotide). Triethylamine (2 eq.) and triphenylphosphine ( 3 eq.) were added, and the mixture was stirred for $6-8 \mathrm{~h}$. The product was precipitated from reaction mixture with a solution of

TABLE 4. ${ }^{1} \mathrm{H}$ NMR chemical shifts in parts per million ( \pm 0.01 ) versus internal sodium 3-trimethylsilyl- $\left[2,2,3,3{ }^{2} \mathrm{H}_{4}\right]$-propionate and ${ }^{31} \mathrm{P}$ NMR chemical shifts in parts per million $( \pm 0.01)$ versus external $\mathrm{H}_{3} \mathrm{PO}_{4}$

\begin{tabular}{|c|c|c|c|c|c|c|c|c|c|c|c|c|}
\hline & \multicolumn{2}{|c|}{$1 \mathrm{a}$} & \multicolumn{2}{|c|}{$1 b$} & \multicolumn{2}{|c|}{$2 a$} & \multicolumn{2}{|c|}{$2 b$} & \multicolumn{2}{|c|}{$3 a$} & \multicolumn{2}{|c|}{$3 b$} \\
\hline & $m^{7} G$ & G & $m^{7} G$ & G & $m^{7} G$ & G & $m^{7} G$ & G & $m^{7} G$ & G & $m^{7} G$ & G \\
\hline $\mathrm{H} 8$ & $-^{a}$ & 8.22 & $-{ }^{a}$ & 8.14 & $9.00^{\mathrm{b}}$ & 8.04 & $9.01^{b}$ & 7.94 & $9.11^{b}$ & 8.01 & 9.08 & 8.01 \\
\hline $\mathrm{H} 1^{\prime}$ & 5.92 & 5.85 & 5.91 & 5.84 & 5.83 & 5.74 & 5.84 & 5.74 & 5.92 & 5.79 & 5.90 & 5.79 \\
\hline $\mathrm{H} 2^{\prime}$ & 4.58 & 4.62 & 4.58 & 4.62 & 4.58 & 4.71 & 4.45 & 4.60 & 4.58 & 4.69 & 4.54 & 4.67 \\
\hline $\mathrm{H} 3^{\prime}$ & 4.46 & 4.47 & 4.46 & 4.47 & 4.49 & 4.54 & $4.42^{\mathrm{C}}$ & $4.42^{\mathrm{C}}$ & 4.50 & 4.49 & 4.49 & 4.42 \\
\hline $\mathrm{H} 4^{\prime}$ & $4.35^{\mathrm{c}}$ & $4.35^{\mathrm{C}}$ & $4.35^{\mathrm{c}}$ & $4.35^{\mathrm{c}}$ & $4.27^{c}$ & $4.36^{\mathrm{c}}$ & $4.36^{\mathrm{C}}$ & $4.39^{c}$ & $4.34^{\mathrm{C}}$ & $4.39^{\mathrm{C}}$ & $4.36^{\mathrm{C}}$ & $4.42^{\mathrm{C}}$ \\
\hline $\mathrm{H} 5^{\prime}$ & $4.38^{\mathrm{c}}$ & $4.31^{\mathrm{C}}$ & $4.38^{\mathrm{C}}$ & $4.31^{\mathrm{C}}$ & 4.42 & $4.27^{\mathrm{C}}$ & $4.39^{c}$ & $4.22^{\mathrm{C}}$ & $4.38^{\mathrm{C}}$ & 4.27 & $4.37^{\mathrm{C}}$ & $4.29^{c}$ \\
\hline $\mathrm{H} 5^{\prime \prime}$ & $4.26^{\mathrm{C}}$ & $4.31^{\mathrm{C}}$ & $4.26^{\mathrm{C}}$ & $4.31^{\mathrm{C}}$ & $4.36^{\mathrm{c}}$ & $4.27^{\mathrm{C}}$ & $4.36^{\mathrm{C}}$ & $4.20^{\mathrm{C}}$ & $4.33^{c}$ & 4.26 & $4.35^{c}$ & 4.29 \\
\hline $\mathrm{CH}_{3}(\mathrm{~N} 7)$ & 4.07 & - & 4.05 & - & 4.06 & - & 4.03 & - & 4.07 & - & 4.07 & - \\
\hline $\mathrm{P} \alpha$ & \multicolumn{2}{|c|}{44.17} & \multicolumn{2}{|c|}{44.17} & \multicolumn{2}{|c|}{-12.37} & \multicolumn{2}{|c|}{-12.37} & \multicolumn{2}{|c|}{-11.26} & \multicolumn{2}{|c|}{-11.26} \\
\hline$P \beta$ & \multicolumn{2}{|c|}{-23.86} & \multicolumn{2}{|c|}{-23.86} & \multicolumn{2}{|c|}{30.27} & \multicolumn{2}{|c|}{30.18} & \multicolumn{2}{|c|}{-23.79} & \multicolumn{2}{|c|}{-23.79} \\
\hline $\mathrm{P} \gamma$ & \multicolumn{2}{|c|}{$\begin{array}{c}-11.29 \\
4 a\end{array}$} & \multicolumn{2}{|c|}{-11.29} & \multicolumn{2}{|c|}{-12.37} & \multicolumn{2}{|c|}{-12.37} & \multicolumn{2}{|c|}{43.66} & \multicolumn{2}{|c|}{$\begin{array}{c}43.26 \\
6 b\end{array}$} \\
\hline & $\mathrm{m}_{2}{ }^{7,2^{\prime}-O} \mathrm{G}$ & G & $\mathrm{m}_{2}{ }^{7,2^{\prime}-O} \mathrm{G}$ & G & $\mathrm{m}_{2}{ }^{7,2^{\prime}-O} \mathrm{G}$ & G & $\mathrm{m}_{2}{ }^{7,2^{\prime}-\mathrm{O}} \mathrm{G}$ & G & $\mathrm{m}_{2}{ }^{7,2^{\prime}-O} \mathrm{G}$ & G & $\mathrm{m}_{2}{ }^{7,2^{\prime}-O} \mathrm{G}$ & G \\
\hline $\mathrm{H} 8$ & $-^{\mathrm{a}}$ & 8.10 & - $^{\mathrm{a}}$ & 8.07 & $9.01^{b}$ & 8.03 & - $^{\mathrm{a}}$ & 8.10 & $-^{a}$ & 8.07 & $9.01^{b}$ & 8.03 \\
\hline $\mathrm{H} 1^{\prime}$ & 5.94 & 5.81 & 5.93 & 5.80 & 5.97 & 5.80 & 5.94 & 5.81 & 5.93 & 5.80 & 5.97 & 5.80 \\
\hline $\mathrm{H} 2^{\prime}$ & 4.26 & 4.68 & 4.21 & 4.66 & 4.24 & 4.68 & 4.26 & 4.68 & 4.21 & 4.66 & 4.24 & 4.68 \\
\hline $\mathrm{H} 3^{\prime}$ & 4.56 & 4.50 & 4.52 & $4.48^{\mathrm{C}}$ & 4.54 & 4.49 & 4.56 & 4.50 & 4.52 & $4.48^{\mathrm{c}}$ & 4.54 & 4.49 \\
\hline $\mathrm{H} 4^{\prime}$ & $4.30^{c}$ & $4.37^{\mathrm{C}}$ & $4.33^{c}$ & $4.35^{\mathrm{C}}$ & $4.33^{c}$ & $4.27_{c}$ & $4.30^{\mathrm{C}}$ & $4.37^{c}$ & $4.33^{c}$ & $4.35^{\mathrm{C}}$ & $4.33^{c}$ & $4.27_{\mathrm{C}}$ \\
\hline $\mathrm{H} 5^{\prime}$ & $4.39^{c}$ & $4.30^{\mathrm{C}}$ & $4.46^{\mathrm{C}}$ & $4.28^{\mathrm{C}}$ & 4.41 & $4.30^{\mathrm{C}}$ & $4.39^{c}$ & $4.30^{c}$ & $4.46^{c}$ & $4.28^{\mathrm{C}}$ & 4.41 & $4.30^{\circ}$ \\
\hline $\mathrm{H} 5^{\prime \prime}$ & $4.30^{c}$ & $4.30^{\mathrm{C}}$ & $4.34^{c}$ & $4.26^{\mathrm{C}}$ & $4.32^{c}$ & $4.27^{c}$ & $4.30^{c}$ & $4.30^{c}$ & $4.34^{c}$ & $4.26^{\mathrm{C}}$ & $4.32^{\mathrm{C}}$ & $4.27^{\mathrm{C}}$ \\
\hline $\mathrm{CH}_{3}$ (N7) & 4.08 & - & 4.07 & - & 4.06 & - & 4.08 & - & 4.07 & - & 4.06 & - \\
\hline $\mathrm{CH}_{3}\left(2^{\prime}-\mathrm{O}\right)$ & 3.59 & - & 3.59 & - & 3.60 & - & 3.59 & - & 3.59 & - & 3.60 & - \\
\hline $\mathrm{P} \alpha$ & 43 & & 43. & & -12 & & -12 & & -11 & & -11 & \\
\hline$P \beta$ & -23 & & -23 & & 30 & & 30 & & -23 & & -23 & \\
\hline $\mathrm{P} \gamma$ & -11 & & -11 & & -12 & & -12 & & 43 & & 43. & \\
\hline
\end{tabular}

${ }^{\mathrm{a}}$ Exchangeable protons.

${ }^{\mathrm{b}}$ Exchangeable but visible protons.

${ }^{\mathrm{c}}$ Approximate value because of signal overlapping. 
anhydrous $\mathrm{NaClO}_{4}$ (1 eq. per one negative charge) in dry acetone $\left(\sim 8 \mathrm{~mL} / 1 \mathrm{~mL}\right.$ of DMF). After cooling at $4^{\circ} \mathrm{C}$, the precipitate was filtered, washed repeatedly with cold, dry acetone, and dried in vacuum over $\mathrm{P}_{4} \mathrm{O}_{10}$. Yields were $80 \%-100 \%$. In the case of $\mathrm{m}^{7} \mathrm{GMP}$, due to its poorer solubility in DMF, a twofold larger excess of reagents was used, and reaction time was extended to $24 \mathrm{~h}$.

\section{General procedure for nucleoside 5'-O-phosphorothioates (9-11)}

A suspension of an appriopriate nucleoside (1 eq., dried overnight in vacuum over $\left.\mathrm{P}_{4} \mathrm{O}_{10}\right)$ in trimethyl phosphate $(1.5 \mathrm{~mL} / 100 \mathrm{mg}$ of nucleoside) was cooled to $0^{\circ} \mathrm{C}$ in ice/water bath. 2,6-dimethylpyridine ( 3 eq.) and $\mathrm{PSCl}_{3}$ (1.5 eq.) were added. The reaction was maintained overnight at $0^{\circ} \mathrm{C}$, then quenched with 10 volumes of water and stirred for $1 \mathrm{~h}$ at room temperature. The product was separated by DEAE Sephadex chromatography using a linear gradient of $0-0.7 \mathrm{M}$ TEAB. Yields: $380 \mathrm{mg}$ of $9(0.67 \mathrm{mmol})$ starting from $257 \mathrm{mg}(0.91 \mathrm{mmol})$ of guanosine (74\%); $57 \mathrm{mg}$ of $10(0.10 \mathrm{mmol})$ starting from $120 \mathrm{mg}(0.42 \mathrm{mmol})$ of $7-$ methylguanosine (24\%); $75 \mathrm{mg}$ of $11(0.13 \mathrm{mmol})$ starting from $70 \mathrm{mg}(0.23 \mathrm{mmol})$ of $7,2^{\prime}$-O-dimethylguanosine (53\%).

\section{Synthesis of nucleoside $5^{\prime}$-O-(2-thiodiphosphates)}

\section{7,2' -O-dimethylguanosine 5' -O-(2-thiodiphosphate) (17)}

To a suspension of $14(100 \mathrm{mg}, 0.21 \mathrm{mmol})$ and thiophosphate triethylammonium salt $(220 \mathrm{mg})$ in $5 \mathrm{~mL}$ of DMF, anhydrous $\mathrm{ZnCl}_{2}$ (190 mg, $1.40 \mathrm{mmol}$ ) was added. The resulting solution was stirred for $20 \mathrm{~min}$ at room temperature. The reaction was quenched by addition of EDTA $(520 \mathrm{mg}, 1.40 \mathrm{mmol})$ in $50 \mathrm{~mL}$ of water and quickly neutralized with solid $\mathrm{NaHCO}_{3}$. The product was isolated on DEAE Sephadex using a 0-1.0 M gradient of TEAB. Yield: $106 \mathrm{mg}(0.15 \mathrm{mmol})$ of $\mathbf{1 7}$ as TEA salt $(71 \%)$.

\section{7-methylguanosine 5'-O-(2-thiodiphosphate) (16)}

This compound was synthesized as described for 17 starting from 13 (40 mg, $0.089 \mathrm{mmol}$ ) and thiophosphate triethylammonium salt $(100 \mathrm{mg})$. Yield: $31 \mathrm{mg}(0.046 \mathrm{mmol})$ of 16 as TEA salt $(52 \%)$.

\section{Synthesis of cap S analogs}

\section{$m^{7} G p p p_{s} G D 1$ and D2 (1a and $\left.\mathbf{1 b}\right)$}

To a suspension of $9(10 \mathrm{mg}, 0.018 \mathrm{mmol})$ and $7(15 \mathrm{mg}, 0.027$ $\mathrm{mmol})$ in DMF $(0.8 \mathrm{~mL})$, anhydrous $\mathrm{ZnCl}_{2}(30 \mathrm{mg}, 0.22 \mathrm{mmol})$ was added. The reaction was maintained for $2 \mathrm{~d}$ at room temperature and then quenched by addition of $90 \mathrm{mg}$ of EDTA in $10 \mathrm{~mL}$ of water and neutralized with solid $\mathrm{NaHCO}_{3}$. The diastereomers $\mathbf{1 a}$ and $\mathbf{1 b}$ were separated by analytical RP HPLC. Yield: $0.8 \mathrm{mg}$ of $\mathbf{1 a}$ and $1.0 \mathrm{mg}$ of $\mathbf{1 b}$ as $\mathrm{NH}_{4}{ }^{+}$salts.

\section{$m^{7} G p p_{s} p G D 1$ and D2 (2a and $\left.\mathbf{2 b}\right)$}

Synthesized and separated as described for $\mathbf{1 a}$ and $\mathbf{1 b}$ starting from $16(20 \mathrm{mg}, 0.030 \mathrm{mmol}), 15(23 \mathrm{mg}, 0.053 \mathrm{mmol})$, and $\mathrm{ZnCl}_{2}$ (60 mg, $0.44 \mathrm{mmol}$ ) in $2 \mathrm{~mL}$ of DMF. Yield: $2.2 \mathrm{mg}$ of $2 \mathrm{a}$ and $1.8 \mathrm{mg}$ of $\mathbf{2} \mathbf{b}$ as $\mathrm{NH}_{4}{ }^{+}$salts. $m^{7} G p_{s} p p G D 1$ and D2 (3a and $\mathbf{3 b}$ )

Synthesized as described for $\mathbf{1 a}$ and $\mathbf{1 b}$ starting from $\mathbf{1 0}(58 \mathrm{mg}$, $0.090 \mathrm{mmol}$ ), 12 (120 mg, $0.22 \mathrm{mmol}$ ), and $\mathrm{ZnCl}_{2}$ (249 mg, 1.8 $\mathrm{mmol}$ ) in $3.5 \mathrm{~mL}$ of DMF. Yield: $14.7 \mathrm{mg}$ of $\mathbf{3 a}$ and $10.1 \mathrm{mg}$ of $3 \mathbf{b}$ as $\mathrm{NH}_{4}{ }^{+}$salts.

$m_{2}{ }^{7,2^{\prime}-\mathrm{O}} G p p p_{s} G D 1$ and D2 (4a and $\left.\mathbf{4 b}\right)$

Compounds 9 (48 mg, $0.084 \mathrm{mmol}$ ) and 8 (57 mg, $0.10 \mathrm{mmol})$ were suspended in $2 \mathrm{~mL}$ of DMF. Subsequently, anhydrous $\mathrm{ZnCl}_{2}$ (115 mg, $0.84 \mathrm{mmol}$ ) was added. The resulting solution was maintained for $2 \mathrm{~d}$ at room temperature. The reaction was quenched by addition of $350 \mathrm{mg}$ of EDTA in $30 \mathrm{~mL}$ of water and neutralized with solid sodium bicarbonate. Products were separated by semipreparative RP HPLC using a linear gradient of methanol in $0.05 \mathrm{M}$ ammonium acetate, $\mathrm{pH} 5.9$, from $0 \%-$ $25 \%$ within $45 \mathrm{~min}$. Yield: $5.2 \mathrm{mg}$ of $\mathbf{4 a}$ and $7.4 \mathrm{mg}$ of $\mathbf{4 b}$ as $\mathrm{NH}_{4}{ }^{+}$ salts.

$m_{2}{ }^{7,2}-\mathrm{O} G p p_{s} p G D 1$ and D2 (5a and $\left.\mathbf{5 b}\right)$

Synthesized as described for $\mathbf{4 a}$ and $\mathbf{4 b}$ starting from $\mathbf{1 7}$ (106 mg, $0.16 \mathrm{mmol}$ ), 15 (103 $\mathrm{mg}, 0.24 \mathrm{mmol}$ ), and $\mathrm{ZnCl}_{2}$ (260 mg, 1.9 $\mathrm{mmol}$ ) in $5 \mathrm{~mL}$ of DMF. The reaction was quenched with $800 \mathrm{mg}$ of EDTA in $100 \mathrm{~mL}$ of water and neutralized with solid sodium bicarbonate. Products were separated by semipreparative RP HPLC using isocratic $0.05 \mathrm{M}$ ammonium acetate, $\mathrm{pH}$ 5.9. Yield: $10.0 \mathrm{mg}$ of $\mathbf{5 a}$ and $12.1 \mathrm{mg}$ of $\mathbf{5 b}$ as $\mathrm{NH}_{4}{ }^{+}$salts.

$m_{2}^{7,2^{\prime}-\mathrm{O}} G p_{s} p p G D 1$ and D2 (6a and $\left.\mathbf{6 b}\right)$

This compound was synthesized as described for 4 starting from 11 (70 mg, $0.15 \mathrm{mmol}), 12$ (107 mg, $0.20 \mathrm{mmol}$ ), and anhydrous $\mathrm{ZnCl}_{2}(220 \mathrm{mg}, 1.6 \mathrm{mmol})$ in $3 \mathrm{~mL}$ of DMF. The reaction was quenched with $650 \mathrm{mg}$ of EDTA in $70 \mathrm{~mL}$ of water. Products were separated by semipreparative RP HPLC using a linear gradient of methanol in $0.05 \mathrm{M}$ ammonium acetate, $\mathrm{pH} 5.9$, from $0 \%-50 \%$ within 45 min. Yield: $15 \mathrm{mg}$ of $\mathbf{6 a}$ and $20 \mathrm{mg}$ of $\mathbf{6 b}$ as $\mathrm{NH}_{4}{ }^{+}$salts.

\section{elF4E fluorescence binding titration}

Mouse eukaryotic initiation factor eIF4E (residues 28-217) was expressed in BL21(DE3) Escherichia coli strain. The protein was purified from inclusion bodies, and guanidinum-solubilized protein was refolded by one-step dialysis and purified by ionexchange chromatography on a HiTrapSP column without contact with cap analogs. The concentration of eIF4E was determined spectrophotometrically $\left(\varepsilon_{280}=53400 \mathrm{~cm}^{-1} \mathrm{M}^{-1}\right)$.

Fluorescence titration measurements were carried out on an LS50B spectrofluorometer (Perkin Elmer Co.) in $50 \mathrm{mM}$ HEPES/ $\mathrm{KOH}(\mathrm{pH} 7.2), 100 \mathrm{mM} \mathrm{KCl}, 0.5 \mathrm{mM}$ EDTA, $1 \mathrm{mM}$ DTT at $20.0 \pm 0.2^{\circ} \mathrm{C}$. Aliquots of $1 \mu \mathrm{L}$ increasing concentration of cap analog solutions were added to $1.4 \mathrm{~mL}$ of $0.1 \mu \mathrm{M}$ protein solutions. Fluorescence intensities (excitation at $280 \mathrm{~nm}$ with 2.5-nm bandwidth and detection at $337 \mathrm{~nm}$ with $4-\mathrm{nm}$ bandwidth and $290 \mathrm{~nm}$ cutoff filter) were corrected taking into account sample dilution and the inner filter effect. Equilibrium association constants $\left(K_{\mathrm{AS}}\right)$ were determined by fitting the theoretical dependence of fluorescence intensity on the total concentration of cap 
analog to the experimental data points, according to the equation described previously (Niedzwiecka et al. 2002). The concentration of protein was fitted as a free parameter of the equilibrium equation showing the amount of "active" protein. The final $K_{\mathrm{AS}}$ was calculated as a weighted average of 3-10 independent titrations, with the weights taken as the reciprocals of the numerical standard deviations squared. Numerical nonlinear least-squares regression analysis was performed using ORGIN 6.0 (Microcal Software Inc.).

The Gibbs free energy of binding was calculated from the $K_{\mathrm{AS}}$ value according to the standard equation $\Delta G^{\circ}=-\mathrm{R} T \ln K_{\mathrm{AS}}$.

\section{Enzymatic hydrolysis of $\mathrm{S}$ analogs with human and $C$. elegans DcpS}

Human and nematode DcpS were expressed in E. coli according to the procedures described previously (Cohen et al. 2004). Both proteins were stored at $-80^{\circ} \mathrm{C}$ in $20 \mathrm{mM}$ Tris buffer, $\mathrm{pH} 7.5$, containing $50 \mathrm{mM} \mathrm{KCl}, 0.2 \mathrm{mM}$ EDTA, $1 \mathrm{mM}$ DTT, $0.5 \mathrm{mM}$ PMSF, and $20 \%$ glycerol. An appropriate cap analog at $4 \mu \mathrm{M}$ concentration was treated with 5.0 or $7.0 \mu \mathrm{L}$ of DcpS (from human or C. elegans, respectively) in $500 \mu \mathrm{L}$ of $50 \mathrm{mM}$ Tris buffer, $\mathrm{pH} 7.9$, containing $20 \mathrm{mM}$ of $\mathrm{MgCl}_{2}$ and $60 \mathrm{mM}$ of $\left(\mathrm{NH}_{4}\right)_{2} \mathrm{SO}_{4}$ at $37^{\circ} \mathrm{C}$ for $60-90 \mathrm{~min}$. Every $15-20 \mathrm{~min}$, a $100-\mu \mathrm{L}$ sample was collected from the reaction mixture and deactivated by incubation for $3 \mathrm{~min}$ at $90^{\circ} \mathrm{C}$. Collected samples were analyzed without further treatment by analytical RP HPLC using a linear gradient of methanol in $0.1 \mathrm{M} \mathrm{KH}_{2} \mathrm{PO}_{4}$, $\mathrm{pH} 6.0$, from $0 \%-50 \%$ within $15 \mathrm{~min}$ and UV detection at $260 \mathrm{~nm}$.

\section{Inhibition of cap-dependent translation}

A micrococcal nuclease-treated rabbit reticulocyte lysate was used for in vitro translation (Cai et al. 1999). Optimal cap-dependent translation was achieved at $100 \mathrm{mM}$ potassium acetate and 1.4 $\mathrm{mM}$ magnesium chloride. To determine inhibition of translation by various cap analogs, natural rabbit globin mRNA was added to the lysate at $5 \mu \mathrm{g} / \mathrm{mL}$, and protein synthesis was measured by incorporation of $\left[{ }^{3} \mathrm{H}\right]$ Leu. Normalization of $\mathrm{K}_{\mathrm{I}}$ data was performed as described previously (Cai et al. 1999). The concentrations of dinucleotide cap analog solutions were measured by UV absorbance at $\mathrm{pH} 7.0$ using $\lambda=255 \mathrm{~nm}$ and $\varepsilon_{\mathrm{M}}=22.6 \times$ $10^{-3} \mathrm{M}$.

\section{ACKNOWLEDGMENTS}

We thank the Laboratory of Biological NMR of the Institute of Biochemistry and Biophysics of the Polish Academy of Sciences (IBB PAS) for access to the NMR apparatus and Jacek Oledzki from the Laboratory of Mass Spectrometry IBB PAS for recording MS spectra. Financial support from a grant from the Howard Hughes Medical Institute to E.D. (No. 55005604), a grant from the Polish Ministry of Science and Higher Education (No. 2 P04A 006 28) and National Science Support Project 2008-2010 No. PBZ-MNiSW-07/I/2007, a grant from the National Institute of General Medical Sciences to R.E.R. (No. R01-GM20818) and a grant from the NIAID to R.E.D. (No. RO1-AI049558) is gratefully acknowledged.

Received January 4, 2008; accepted February 18, 2008.

\section{REFERENCES}

Baraniak, J. and Frey, P.A. 1988. Effect of ion pairing on bond order and charge localization in alkyl phosphorothioates. J. Am. Chem. Soc. 110: 4059-4060.

Cai, A., Jankowska-Anyszka, M., Centers, A., Chlebicka, L., Stepinski, J., Stolarski, R., Darzynkiewicz, E., and Rhoads, R.E. 1999. Quantitative assessment of mRNA cap analogues as inhibitors of in vitro translation. Biochemistry 38: 8538-8547.

Carberry, S.E., Rhoads, R.E., and Goss, D.J. 1989. A spectroscopic study of the binding of $\mathrm{m}^{7} \mathrm{GTP}$ and $\mathrm{m}^{7} \mathrm{GpppG}$ to human protein synthesis initiation factor 4E. Biochemistry 28: 8078-8083.

Cohen, L.S., Mikhli, C., Friedman, C., Jankowska-Anyszka, M., Stepinski, J., Darzynkiewicz, E., and Davis, R.E. 2004. Nematode $\mathrm{m}^{7} \mathrm{GpppG}$ and $\mathrm{m}_{3}{ }^{2,2,7} \mathrm{GpppG}$ decapping: Activities in Ascaris embryos and characterization of C. elegans scavenger DcpS. RNA 10: 1609-1624.

Coller, J. and Parker, R. 2004. Eukaryotic mRNA decapping. Annu. Rev. Biochem. 73: 861-890.

Connolly, B.A., Romaniuk, P.J., and Eckstein, F. 1982. Synthesis and characterization of diastereomers of guanosine $5^{\prime}-\mathrm{O}$-(1-thiotriphosphate) and guanosine $5^{\prime}$-O-(2-thiotriphosphate). Biochemistry 21: 1983-1989.

Contreras, R., Cheroutre, H., Degrave, W., and Fiers, W. 1982. Simple, efficient in vitro synthesis of capped RNA useful for direct expression of cloned eukaryotic genes. Nucleic Acids Res. 10: 6353-6362. doi: 10.1093/nar/10.20.6353.

Darzynkiewicz, E., Ekiel, I., Tahara, S.M., Seliger, L.S., and Shatkin, A.J. 1985. Chemical synthesis and characterization of 7-methylguanosine cap analogs. Biochemistry 24: 1701-1707.

De Benedetti, A. and Graff, J.R. 2004. eIF-4E expression and its role in malignancies and metastases. Oncogene 23: 3189-3199.

Eckstein, F. 1985. Nucleoside phosphorothioates. Annu. Rev. Biochem. 54: $367-402$.

Eckstein, F. and Goody, R.S. 1976. Synthesis and properties of diastereoisomers of adenosine $5^{\prime}$-(O-1-thiotriphosphate) and adenosine 5'-(O-2-thiotriphosphate). Biochemistry 15: 16851691.

Frey, P.A. and Sammons, R.D. 1985. Bond order and charge localization in nucleoside phosphorothioates. Science 228: 541545.

Furuichi, Y. and Shatkin, A.J. 2000. Viral and cellular mRNA capping: Past and prospects. Adv. Virus Res. 55: 135-184.

Gingras, A.C., Raught, B., and Sonenberg, N. 1999. eIF4 initiation factors: Effectors of mRNA recruitment to ribosomes and regulators of translation. Annu. Rev. Biochem. 68: 913-963.

Grudzien, E., Kalek, M., Jemielity, J., Darzynkiewicz, E., and Rhoads, R.E. 2006. Differential inhibition of mRNA degradation pathways by novel cap analogs. J. Biol. Chem. 281: 1857-1867.

Grudzien-Nogalska, E., Jemielity, J., Kowalska, J., Darzynkiewicz, E., and Rhoads, R.E. 2007. Phosphorothioate cap analogs stabilize mRNA and increase translational efficiency in mammalian cells. RNA 13: 1745-1755.

Gu, M., Fabrega, C., Liu, S.W., Liu, H., Kiledjian, M., and Lima, C.D. 2004. Insights into the structure, mechanism, and regulation of scavenger mRNA decapping activity. Mol. Cell 14: 67-80.

Ho, H.T. and Frey, P.A. 1984. A new method for synthesizing phosphoanhydrides: Synthesis of adenosine 5'-(2-thiodiphosphate) and adenosine 5'-(2-thiotriphosphate). Biochemistry 25: 1978-1983.

Jemielity, J., Fowler, T., Zuberek, J., Stepinski, J., Lewdorowicz, M., Niedzwiecka, A., Stolarski, R., Darzynkiewicz, E., and Rhoads, R.E. 2003. Novel "anti-reverse" cap analogs with superior translational properties. RNA 9: 1108-1122.

Jones, J.W. and Robins, R.K. 1963. Purine nucleosides. III. Methylation studies of certain naturally occurring purine nucleosides. J. Am. Chem. Soc. 85: 193-201.

Kadokura, M., Wada, T., Urashima, C., and Sekine, M. 1997. Efficient synthesis of $\gamma$-methyl-capped guanosine $5^{\prime}$-triphosphate as a 
5 '-terminal unique structure of U6 RNA via a new triphosphate bond formation involving activation of methyl phosphorimidazolidate using $\mathrm{ZnCl}_{2}$ as a catalyst in DMF under anhydrous conditions. Tetrahedron Lett. 38: 8359-8362.

Kalek, M., Jemielity, J., Grudzien, E., Zuberek, J., Bojarska, E., Cohen, L.S., Stepinski, J., Stolarski, R., Davis, R.E., Rhoads, R.E., et al. 2005. Synthesis and biochemical properties of novel mRNA $5^{\prime}$-cap analogs resistant to enzymatic hydrolysis. Nucleosides Nucleotides Nucleic Acids 24: 615-621.

Kalek, M., Jemielity, J., Darzynkiewicz, Z.M., Bojarska, E., Stepinski, J., Stolarski, R., Davis, R.E., and Darzynkiewicz, E. 2006. Enzymatically stable 5' mRNA cap analogs: Synthesis and binding studies with human DcpS decapping enzyme. Bioorg. Med. Chem. 14: 3223-3230.

Konarska, M.M., Padgett, R.A., and Sharp, P.A. 1984. Recognition of cap structure in splicing in vitro of mRNA precursors. Cell 38: 731-736.

Kowalska, J., Lewdorowicz, M., Darzynkiewicz, E., and Jemielity, J. 2007. A simple and rapid synthesis of nucleotide analogues containing a phosphorothioate moiety at the terminal position of the phosphate chain. Tetrahedron Lett. 48: 54755479.

Kusmierek, J. and Shugar, D. 1978. A new route to $2^{\prime}\left(3^{\prime}\right)-O$-alkyl purine nucleosides. Nucleic Acids Res. Special Publ. No. 4: s73s77.

Li, P., Xu, Z., Liu, H., Wennefors, C.K., Dobrikov, M.I., Ludwig, J., and Shaw, B.R. 2005. Synthesis of $\alpha$-P-modified nucleoside diphosphates with ethylenediamine. J. Am. Chem. Soc. 127: 16782-16783.

Lima, C.D., Klein, M.G., and Hendrickson, W.A. 1997. Structurebased analysis of catalysis and substrate definition in the HIT protein family. Science 278: 286-290.

Liu, H., Rodgers, N.D., Jiao, X., and Kiledjian, M. 2002. The scavenger mRNA decapping enzyme DcpS is a member of the HIT family of pyrophosphatases. EMBO J. 21: 4699-4708.

Ludwig, J. and Eckstein, F. 1989. Rapid and efficient synthesis of nucleoside $5^{\prime}$-O-(1-thiotriphosphates), $5^{\prime}$-triphosphates and $2^{\prime}, 3^{\prime}$ cyclophosphorothioates using 2-chloro-4H-1,3,2-benzodioxaphosphorin-4-one. J. Org. Chem. 54: 631-635.

McCubbin, W.D., Edery, I., Altmann, M., Sonenberg, N., and Kay, C.M. 1988. Circular dichroism and fluorescence studies on protein synthesis initiation factor eIF-4E and two mutant forms from the yeast Saccharomyces cerevisiae. J. Biol. Chem. 263: 1766317671.

Mitchell, D.A. and Nair, S.K. 2000. RNA-transfected dendritic cells in cancer immunotherapy. J. Clin. Invest. 106: 1065-1069.
Mockey, M., Goncalves, C., Dupuy, F.P., Lemoine, F.M., Pichon, C., and Midoux, P. 2006. mRNA transfection of dendritic cells: Synergistic effect of ARCA mRNA capping with Poly(A) chains in cis and in trans for a high protein expression level. Biochem. Biophys. Res. Commun. 340: 1062-1068.

Moran, J.R. and Whitesides, G.M. 1984. A practical enzymatic synthesis of $\left(\mathrm{S}_{[\mathrm{P}]}\right)$-adenosine $5^{\prime}-\mathrm{O}$-(1-thiotriphosphate) $\left(\left(\mathrm{S}_{\mathrm{P}}\right)\right.$ ATP- $\alpha-S)$. J. Org. Chem. 49: 704-706.

Mukaiyama, T. and Hashimoto, M. 1971. Phosphorylation by oxidation-reduction condensation. Preparation of active phosphorylating reagents. Bull. Chem. Soc. Jpn. 44: 2284.

Niedzwiecka, A., Marcotrigiano, J., Stepinski, J., JankowskaAnyszka, M., Wyslouch-Cieszynska, A., Dadlez, M., Gingras, A.C., Mak, P., Darzynkiewicz, E., Sonenberg, N., et al. 2002. Biophysical studies of eIF4E cap-binding protein: Recognition of mRNA $5^{\prime}$-cap structure and synthetic fragments of eIF4G and 4E-BP1 proteins. J. Mol. Biol. 319: 615-635.

Pasquinelli, A.E., Dahlberg, J.E., and Lund, E. 1995. Reverse 5' caps in RNAs made in vitro by phage RNA polymerases. RNA 1: 957967.

Peng, Z.H., Sharma, V., Singleton, S.F., and Gershon, P.D. 2002. Synthesis and application of a chain-terminating dinucleotide mRNA cap analog. Org. Lett. 4: 161-164.

Richard, J.P. and Frey, P.A. 1982. Synthesis of chiral $\left[{ }^{18} \mathrm{O}\right]$ phosphorothioate analogs of adenine nucleotides. J. Am. Chem. Soc. 104: 3476-3481.

Richter, J.D. and Sonenberg, N. 2005. Regulation of cap-dependent translation by eIF4E inhibitory proteins. Nature 433: 477-480.

Saenger, W. and Eckstein, F. 1970. Stereochemistry of a substrate for pancreatic ribonuclease. Crystal and molecular structure of the triethylammonium salt of uridine $2^{\prime}, 3^{\prime}-O, O$-cyclophosphorothioate. J. Am. Chem. Soc. 92: 4712-4718.

Stepinski, J., Waddell, C., Stolarski, R., Darzynkiewicz, E., and Rhoads, R.E. 2001. Synthesis and properties of mRNAs containing the novel "anti-reverse" cap analogs 7-methyl(3'-Omethyl)GpppG and 7-methyl(3'-deoxy)GpppG. RNA 7: 1486-1495.

van Dijk, E., Cougot, N., Meyer, S., Babajko, S., Wahle, E., and Seraphin, B. 2002. Human Dcp2: A catalytically active mRNA decapping enzyme located in specific cytoplasmic structures. EMBO J. 21: 6915-6924.

Wang, Z., Jiao, X., Carr-Schmid, A., and Kiledjian, M. 2002. The hDcp2 protein is a mammalian mRNA decapping enzyme. Proc. Natl. Acad. Sci. 99: 12663-12668.

Yisraeli, J.K. and Melton, D.A. 1989. Synthesis of long, capped transcripts in vitro by SP6 and T7 RNA polymerases. Methods Enzymol. 180: 42-50. 

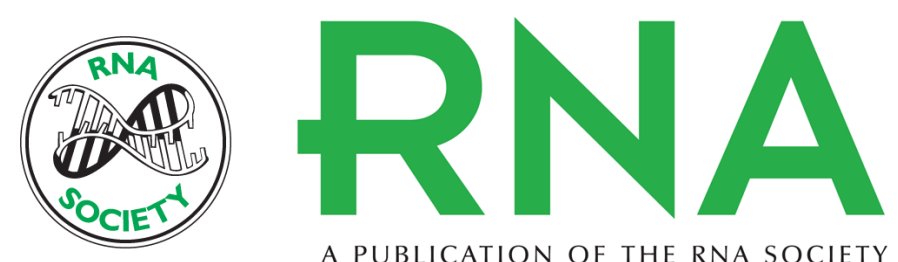

A PUBLICATION OF THE RNA SOCIETY

\section{Synthesis and characterization of mRNA cap analogs containing phosphorothioate substitutions that bind tightly to elF4E and are resistant to the decapping pyrophosphatase DcpS}

Joanna Kowalska, Magdalena Lewdorowicz, Joanna Zuberek, et al.

RNA 2008 14: 1119-1131

References This article cites 45 articles, 12 of which can be accessed free at:

http://rnajournal.cshlp.org/content/14/6/1119.full.html\#ref-list-1

License

Email Alerting Receive free email alerts when new articles cite this article - sign up in the box at the

Service top right corner of the article or click here.

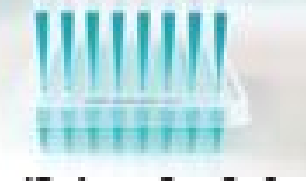

Providing Precise Solutions for your research.

To subscribe to RNA go to:

http://rnajournal.cshlp.org/subscriptions 